\title{
Beyond Promissory Estoppel: Contract Law and the "Invisible Handshake"
}

\author{
Daniel A. Farber $\dagger$ \\ John H. Mathesont†
}

Employers do, in fact, rely heavily on the "invisible handshake" as a substitute for the invisible hand that cannot operate effectively in the career labor market. While nonunion firms do make commitments that are morally, and even legally, binding for a year ahead on wage rates (and, for some salaried employees, on total earnings), they generally opt for implicit rather than explicit contracts beyond that period. Apparently employers believe they can influence the long-term expectations of workers favorably with nonbinding statements that preserve much of their own flexibility.

Arthur Okun ${ }^{1}$

As every law student knows, promissory estoppel is based on detrimental reliance. Law students share this idea with the American Law Institute ${ }^{2}$ and with treatise writers. ${ }^{3}$ Indeed, promissory estoppel is one of the few points of agreement between the critical legal scholars on the left and the law and economics writers on tbe right. Both agree that reliance has been the foundation of promis-

$\dagger$ Professor of Law, University of Minnesota.

t† Associate Professor of Law, University of Minnesota.

The authors wish to thank Professors Allan Farnsworth, Bob Hudec, Ian Macneil, Bob Scott, and the participants in faculty colloquia at New York University and the University of Virginia for their helpful comments on previous drafts.

1 Arthur Okun, Prices and Quantities: A Macroeconomic Analysis 89 (1981).

2 See Restatement (Second) of Contracts $\$ 90$ (1981), which reads as follows:

$\S$ 90. Promise Reasonably Inducing Action or Forbearance:

(1) A promise which the promisor should reasonably expect to induce action or forbearance on the part of the promisee or a third person and which does induce such action or forbearance is binding if injustice can be avoided only by enforcement of the promise. The remedy granted for breach may be limited as justice requires.

(2) A charitable subscription or a marriage settlement is binding under Subsec-

tion (1) without proof that the promise induced action or forbearance.

For discussions of the differences between the versions of section 90 in REsTatemENT of Contracts (1932) [hereinafter cited as Restatement] and Restatement (Second) of CoNTRACTS (1981) [hereinafter cited as RESTATEMENT (Second)], see Eisenberg, The Principles of Consideration, 67 ConNell L. REv. 640, 657-59 (1982); Knapp, Reliance in the Revised Restatement: The Proliferation of Promissory Estoppel, 81 Colum. L. REv. 52, 55-61 (1981).

s See, e.g., 1A Arthur Corbin, Contracts § 200, at 215-21 (1963); E. Allen Farnsworth, Contracts $\S 2.19$, at 93-94 (1982); John Murray, Contracts $\S 93$, at 203-06 (1974). 
sory estoppel, ${ }^{4}$ and both accuse the courts of incoherence in applying the doctrine. ${ }^{5}$

We have recently surveyed over two hundred promissory estoppel cases decided in the last ten years. ${ }^{6}$ Our conclusion is that reliance is no longer the key to promissory estoppel. ${ }^{7}$ Although courts still feel constrained to speak the language of reliance, their holdings can best be understood and harmonized on other grounds.

Part I of this article reports the results of our survey. It documents the declining role of reliance in establishing liability and determining remedies. It also suggests that most cases denying recovery, purportedly for lack of reasonable reliance, can be readily explained on other grounds. Part II explores the implications of these findings. We believe that a new rule of promissory liability is emerging from the courts' encounters with an economy in which Okun's "invisible handshake" is increasingly important. The rule is

- For critical legal studies approaches, see Feinman, Critical Approaches to Contract Law, 30 UCLA L. REv. 829, 854-56 (1983) (discussing Hoffman v. Red Owl Stores, Inc., 26 Wis. $2 d$ d 683,133 N.W.2d 267 (1967), as recognizing reliance theory of contract); Mensch, Book Review, 33 Stan. L. Rev. 753, 769-70 (1981) (reviewing Patrick Atiyah, The RISe and FaLl of Freedom of Contract (1979)) (critiquing use of a reliance vocabulary). On the law and economics side, see Goetz \& Scott, Enforcing Promises: An Examination of the Basis of Contract, 89 YALE L.J. 1261, 1266-70, 1314-21 (1980) (discussing reliance, defined as consumption changes made by plaintiffs in anticipation of fulfillment of promises, as basis of promissory enforceinent).

- See Feinman, Promissory Estoppel and Judicial Method, 97 HARv. L. REv. 678, 71618 (1984); Goetz \& Scott, supra note 4, at 1320-21; Mensch, supra note 4, at 769-70.

${ }^{6}$ For a description of the survey, see infra note 14 .

7 That the reliance interest is central to contract law in general has been recognized since the publication of Fuller \& Perdue, The Reliance Interest in Contract Damages (pts. $1 \&$ 2), 46 YALE L.J. 52, 373 (1936-37). Even the drafters of the second Restatement recognized that "[c]ertainly reliance is one of the main bases for enforcement of the half-completed excbange, and the probability of reliance lends support to the enforcement of the executory exchange." RESTATEMENT (SECOND) § 90 comment a; see also Dalton, An Essay in the Deconstruction of Contract Doctrine, 94 YaLE L.J. 997, 1089 (1985) ("If we take seriously the idea of reliance as a basis for enforcing promises, it is hard to see why we would ever invoke the doctrine of consideration, even in situations where we currently think consideration would be found."). There is a difference, lowever, between the use of the reliance concept in the domain of traditional contract law and its use in the domain of promissory estoppel: only under promissory estoppel must some tangible, reliance-based injury, apart from disappointed expectations, be proved in each case not merely to measure damages, but to establish the cause of action. Accord Charles Fried, Contract as Promise: A Theory of Contractual Obligation 5 n.* (1981) (for the "Death of Contract" theorist, "a cognizable injury must be a palpable loss identifiable apart from the expectation that the promise will be kept"). In the executory contract setting, by comparison, it is recognized that "[t]o encourage reliance we must . . . dispense with its proof." Fuller \& Perdue, supra, at 62; see also E. A. FARNSwORTH, supra note $3, \S 1.6$, at 18.

When we state that our proposed rule is not reliance-based, we mean that it does not base recovery upon proof of reliance in the individual case. The policy we seek to promote, however, is one of encouraging reliance. See infra notes 93-97 and accompanying text. 
quite simple: any promise made in furtherance of an economic activity is enforceable. ${ }^{8}$

Our proposed rule unifies promissory estoppel and other exceptions to the consideration requirement ${ }^{9}$ with consideration doctrine itself. In each instance, the underlying legal policy is to protect the ability of individuals to trust promises in circumstances in which that trust is socially beneficial. Traditional consideration doctrine allows trust to function in contexts such as sales, leases, insurance, and loans-key economic arrangements that could not function effectively without legal enforceability. ${ }^{10}$ Promises involving firm offers, sureties, and options are enforceable without consideration because some economically useful transactions would otherwise be difficult to structure. Promissory estoppel fills a similar function by enforcing promises in other settings not amenable to traditional bargaining transactions, in which reliance is beneficial both to the promisor and to society as a whole.

In our view, the expansion of promissory estoppel is not, as some have argued, proof that contract is in the process of being swallowed up by tort. ${ }^{11}$ Rather, promissory estoppel is being transformed into a new theory of distinctly contractual obligation. ${ }^{12} \mathrm{We}$

- This rule is set out in detail in a proposed section for the third Restatement, infra at text accompanying notes 99-108.

- See, e.g., U.C.C. § 2-205 (1978) (firm offer rule); RestatBment (Second) § 87 (option contract); id. $\$ 88$ (guaranty).

${ }^{10}$ See Farber, Contract Law and Modern Economic Theory, 78 Nw. U.L. Rev. 303, 315-18 (1983).

11 See Grant Gllmore, The Death of Contract 87 (1974) (“' contract' is being reabsorbed into the mainstream of 'tort' ").

The essence of the association of promissory estoppel witb tort law is its focus on remedying the injury caused by reliance on the careless use of promissory language. See Feinman \& Feldman, Pedagogy and Politics, 73 GEo. L.J. 875, 884 (1985). According to the drafters of the second Restatement,

Obligations and remedies based on rehance are not peculiar to the law of contracts.

This Section is often referred to in terms of "promissory estoppel," a phrase suggesting an extension of the doctrine of estoppel. Estoppel prevents a person from showing the truth contrary to a representation of fact made by him after another has relied on the representation. See Restatement, Second, Agency \& 8B; Restatement, Second, Torts $\$ \S 872,894$. Reliance is also a significant feature of numerous rules in the law of neghgence, deceit and restitution. See, e.g., Restatement, Second, Agency $\S$ 354, 378; Restatement, Second, Torts $\S \S 323,537$; Restatement of Restitution $\S 55$. In some cases those rules and this Section overlap; in others they provide analogies useful in determining the extent to which enforcement is necessary to avoid injustice.

Restatement (Second) $\S 90$ coinment a (1981). Some commentators also suggest that the remedy for detrimental reliance should be a tort action to recover rehance damages. See Richard Posner, Economic ANalysis of Law 70 (2d ed. 1977); Goetz \& Scott, supra note 4, at 1274-75 (drawing analogy between broken promises and defective products).

12 An analysis of the difference between contract and tort would occupy a treatise, particularly if the discussion were to be historically sensitive. See G. GLMORE, supra note 11, at 


\section{also think, for reasons that will appear more fully in Part II, that} our proposed rule not only harmonizes many otherwise inconsistent cases, but also furthers the often divergent values proclaimed by the law and economics writers and the critical legal scholars. Besides serving the interest of economic efficiency, our proposed rule also furthers the important moral value of mutual trust. ${ }^{13}$

87 ("It should be pointed out that the theory of tort into which contract is being reabsorbed is itself a much more expansive theory of liability than was the theory of tort from which contract was artificially separated a hundred years ago."). It is also possible that general theories of the role of legal' rules are of more significance in contemporary legal discourse than are the doctrinal differences between contract and tort. For example, the emphasis in law and economics scholarship on the design of Iegal rules to affect behavior ex ante is a substantial reorientation of tort law from its traditional concern with compensation for injury ex post. See, e.g., Goetz \& Scott, supra note 4, at 1274-75 (basing damage formula for breach of promise on tort theory, but characterizing their approach as "equivalent . . . to the balancing of prospective costs and benefits under the widely accepted Learned Hand test for the required duty of care-in potential tort-producing activities"). See generally R. POSNER, supra note 11, at 119-59 (discussing economic analysis of tort law). Gilmore did suggest, after all, that it may well be the fate of both tort and contract "to be swallowed up in a generalized theory of civil obligation." G. GHMORE, supra note 11, at 941.

Nonetheless, there does still seem to be some sense in distingnishing between contractbased and tort-based theories of ohligation, if only to be able to document the closing of the gaps between them. The classical starting poimt of contract law is the autonomous domain of voluntary private ordering. See, e.g., OLIver Wendell Holmes, JR., The Common Law 299-303 (1881); William Story, a Treatise on the Law of Contracts Not Under Seal $\S \S 7-12$ (2d ed. Boston 1847). Classical contract law is highly individualistic, as befits its origins in a period dominated by laissez-faire economics. See LaURENCE M. FrIEdMan, ConTract Law in America: A Social and Economic Case Study 20-22 (1965); Cohen, The Basis of Contract, 46 Harv. L. REv. 553, 557-59 (1933); Kessler, Contracts of Adhesion-Some Thoughts about Freedom of Contract, 43 CoLum. L. REv. 629, 629-31, 640 (1943). But stripped of its heightened individualism, contract law, with its stress on the creation and internal dynamics of economically productive relationships, remains a vital source of support for long-term planning and coordination in social relationships. See generally IAN MAcnetu, The New Social Contract (1980) [hereinafter cited as I. Macneil, Social Contract]. Tort law, in contrast, originates in protection of the independent individual's right to be free of interference that is unreasonable according to community standards. See, e.g., WILliam Prosser, HandBook of the Law of Torts 6 (1971) ("The common thread woven into all torts is the idea of unreasonable interference with the interest of others."). Tort law has been a valuable source of authority for those seeking to supervene voluntary arrangements in the interest of social welfare. See, e.g., Kronman, Book Review, 91 YaLE L.J. 404, 406 (1981) (reviewing Chardes Fried, Contract as Promise (1981)) ("Tort law deals with the conflicts arising from involuntary transactions .... In tort law, . . the will of the parties cannot be controlling; here, courts must of necessity take their cue from the 'community's sense of fairness' and other collective standards."). But the core concepts of tort law continue to stress compensation for injury to individual activity. It is in the sense of concern witb the affirmative creation of economic relationships, as opposed to the avoidance of interference with autonomous action, that our theory places its expansion of promissory estoppel flrmly within the domain of contract-while trying at the same time to imbue contract law with some of the concern with community standards that has been the attraction of tortbased theories of promissory obligation.

${ }^{13}$ See infra text accompanying notes 133-34. 


\section{Promissory Estoppel Today: The Changing Framework of ENFORCEMENT}

To investigate the current evolution of promissory estoppel, we undertook a systematic review of the recent cases. We collected every case in the past ten years citing section 90 of either Restatement, ${ }^{14}$ and categorized the outcomes. The results were somewhat unexpected.

\section{A. The Expansion of Promissory Estoppel}

Our first finding concerned the range of cases in which promissory estoppel was applied. Despite its tentative origins and its initial restriction to donative promises, ${ }^{16}$ promissory estoppel is regularly applied to the gamut of commercial contexts. ${ }^{16}$ Classic construction bid cases appear often, as do employee compensation and pension cases. ${ }^{17}$ But promissory estoppel has also been invoked in cases involving lease agreements, stock purchases, and promissory notes. ${ }^{18}$

"Shepard's Citations, Restatement of the Law, Vol. 9, No. 3 (May 1985), identified 222 of such cases. These cases formed our primary data base. As an alternative measure of the popularity of promissory estoppel, we ran a LEXIS search (Genfed and States libraries) for cases since January 1,1980 , that use the term "promissory estoppel." We also reviewed the 540 cases identified by this searcb. Many of these cases, however, merely mentioned the doctrine without applying it. The numbers and percentages discussed in subsequent footnotes are all based on the primary data base of 222 cases. A list of these cases is on file with The University of Chicago Law Review.

The sample period includes 1981, the year of the adoption of the second Restatement. The differences between the versions of section 90 in the first and second Restatements are discussed in Eisenberg, supra note 2, at 657-59, and Knapp, supra note 2, at 55-61.

15 See, e.g., 1 Samuld Williston, A Treatise on the Law of Contracts $§ \S 139,140$ (3d ed. 1936); Boyer, Promissory Estoppel: Requirements and Limitations of the Doctrine, 98 U. PA. L. REv. 459, 461-70, 491-93 (1950).

16 The second Restatement contemplates the applicability of section 90 to commercial contexts. See, e.g., Restatement (SEcond) $\$ 90$ comments b, e (discussing commercial settings). For a general review of several categories of commercial cases to which promissory estoppel has been applied, see Metzger \& Phillips, The Emergence of Promissory Estoppel as an Independent Theory of Recovery, 35 Rutgers L. REv. 472, 513-28 (1983) (discussing subcontractor bid cases, promises by employers, promises by franchisors, credit-related promises, promises related to corporate acquisitions, and promises by public utilities).

17 Of our sample of 222 cases, 31 involved construction and 43 involved employment.

18 See, e.g., Mesa Petroleum Co. v. Coniglio, 629 F.2d 1022, 1027 (5th Cir. 1980) (promissory note; granting recovery on promissory estoppel theory); Gruen Industries, Inc. v. Biller, 608 F.2d 274, 280-82 (7th Cir. 1979) (stock purchase; court rejected promissory estoppel claim because reliance not reasonable under the circumstances); Republic Nat'1 Bank v. Sabet, 512 F. Supp. 416, 425-26 (S.D.N.Y. 1981) (promissory note; rejecting claim for failure to prove detrimental reliance), aff'd mem., 681 F.2d 802 (2d Cir. 1981), cert. denied, 456 U.S. 976 (1982); Coley v. Lang, 339 So. 2d 70, 75 (Ala. Civ. App. 1976) (stock purchase; denying recovery due to lack of detrimental reliance); Kramer v. Alpine Valley Resort, Inc., 
Second, promissory estoppel is no longer merely a fall-back theory of recovery. Rather, courts are now comfortable enough with the doctrine to use it as a primary basis of enforcement. Courts often "decline to address the issue of whether a contract was ever formed between the parties,"19 relying instead on promissory estoppel even when no apparent barrier exists to recovery on a traditional contract theory. ${ }^{20}$

108 Wis. $2 \mathrm{~d} 417,422-25,321$ N.W.2d 293, 295-97 (1982) (holding that terms of lease not a defense to promissory estoppel claim related to other aspects of business relationship); Wamser v. Bamberger, 101 Wis. 2d 637, 644-45, 305 N.W.2d 158, 161 (Ct. App. 1981) (stock purchase; rejecting promissory estoppel as bar to assertion of statute of frauds).

18 Preload Techuology, Inc. v. A.B. \& J. Constr. Co., 696 F.2d 1080, 1084 n.6 (5th Cir. 1983); see also John Price Assocs. v. Warner Elec., Inc., 723 F.2d 755, 757 (10th Cir. 1983) ("We need not address the propriety of the trial court's finding that a contract existed between Price and Warner, since we agree that the doctrine of promissory estoppel barred Warner from withdrawing its bid."); Glover v. Sager, 667 P.2d 1198, 1202 (Alaska 1983) (finding prima facie liability first under promissory estoppel, then under contract principles); Larabee v. Bootb, 463 N.E.2d 487, 491 (Ind. Ct. App. 1984) ("The evidence was suffcient to prove a binding contract under the doctrine of promissory estoppel.").

This finding bears out Henderson's early observatiou that promissory estoppel often forms the basis of decision in cases involving bargain transactions. See Henderson, Promissory Estoppel and Traditional Contract Doctrine, 78 YaLE L.J. 343 (1969). Henderson wrote that he had "uucovered more than 100 decisions . . . in which promissory estoppel was considered as the ground of decision in a clear bargain transaction. In more than onethird of those cases, the theory of Section 90 was used as the sole or alternative basis for enforcement." Id. at 352 n.37. Our survey, as well as Henderson's, demonstrates that it is not the case that "courts apply the doctrines sequentially; only if they find no consideration do courts invoke detrimental rehance." Dalton, supra note 7, at 1090 (suggesting that courts have avoided collapsing consideration into promissory estoppel by giving consideration "procedural priority").

${ }^{20}$ The use of promissory estoppel to avoid one such barrier, the statute of frauds, began early in the development of the doctrine. Indeed, while section 90 of the first Restatement did not use the term promissory estoppel, comment $f$ to section 178 , involving the statute of frauds, did. RESTATEMENT $\$ 178$ comment $\mathrm{f}$ ("[A] promise to make a memorandum, if [substantially] relied on, may give rise to an effective promissory estoppel if the Statute would otberwise operate to defraud."). See, e.g., Klinke v. Famous Recipe Fried Chicken Inc., 94 Wash. 2d 255, 258-62, 616 P.2d 644, 646-48 (1980) (holding promissory estoppel a defense to statute of frauds under Washington common law).

Promissory estoppel is often invoked in cases in which non-substantive barriers to contractual recovery exist. Of the 222 cases in our primary sample, 28 , or more than ten percent, were disposed of under the statute of frauds, the statute of limitations, or the parole evidence rule. In some of these cases, recovery was granted without reaching the promissory estoppel claim. See, e.g., Quaney v. Tobyne, 236 Kan. 201, 689 P.2d 844, 852 (1984) (holding promissory estoppel claim moot because case falls within U.C.C. exceptions to statute of frauds); Opdyke Inv. Co. v. Norris Grain Co., 413 Mich. 354, 368-69, 320 N.W.2d 836, 841-42 (1982) (holding memorandum sufficient to satisfy writing requirement of statute of frauds). In others, recovery was denied despite the promissory estoppel claim. See, e.g., Lige Dickson Co. v. Union Oil Co., 96 Wash. 2d 291, 292, 635 P.2d 103, 107 (1981) (holding promissory estoppel not a defense to the U.C.C. statute of frauds because of supervening policy considerations). For an instance in which promissory estoppel was found to interfere with the requirements of a specific area of law, see Acri v. International Ass'n of Machinists, 595 F. 
Third, reliance plays little role in the determination of remedies. This should not be cause for surprise-the first Restatement of Contracts contemplated full enforcement of promises even when reliance was the basis for enforcement. ${ }^{21}$ But some important early cases limited recovery to reliance damages, ${ }^{22}$ and the drafters of the second Restatement found it necessary to accommodate such limitations: they stated that "recognition of the possibility of partial enforcement" was their major innovation. ${ }^{23}$ Despite this possibility, however, recent cases are heavily weighted towards the award of full expectation damages. ${ }^{24}$ The amount of awards for lost profits may be substantial. ${ }^{25}$ Courts are also willing to grant equi-

Supp. 326, 330-31 (N.D. Cal. 1983) (rejecting application of promissory estoppel to duty of fair representation cases because it would interfere with required proof of proximate cause).

${ }^{21}$ Unlike the second Restatement, the first Restatement did not expressly state that the remedy for breach of promise could be different from that for breach of contract. For the famous debate between Coudert and Williston on this point, see 4 A.L.I. Proc. 98-99, 103-04 app. (1926).

22 See, e.g., Goodman v. Dicker, 169 F.2d 684, 685 (D.C. Cir. 1948) (granting reliance damages rather than expectation damages, where rehance measure produced the larger award); Hoffman v. Red Owl Stores, Inc., 26 Wis. 2d 683, 700-01, 133 N.W.2d 267, 276-77 (1965) (using reliance measure, where expectation award would have been speculative).

23 Restatement (Second) $\$ 90$ reporter's note.

24 The courts addressed the issue of the extent of recovery in 72 of the cases in our data group. In only one-sixth of those cases was recovery limited explicitly to reliance damages. Full expectation recovery was granted in the remaining five-sixths of the cases.

These figures may, however, convey a false sense of certainty. Depending on how the expectation and reliance interests are conceptualized, the two measures may tend to produce the same results. See Fuller \& Perdue, supra note 7, at 73-75. The reliance and expectation measures converge, for example, in the typical subcontract-bidding case. See, e.g., Janke Constr. Co. v. Vulcan Materials Co., 386 F. Supp. 687, 698 (W.D. Wis. 1974) (measure of recovery is the cost of substitute performance minus the defendant's original bid price), aff'd, 527 F.2d 772 (7th Cir. 1976). The argument can also be made that the rehance interest may often best be protected by an expectation measure of damages. See Feinman, supra note 5 , at 687-88 (suggesting that courts may be using expectation recovery in promissory estoppel cases because it is more consistent with the commercial context); Fuller \& Perdue, supra note 7, at 60-61 (expectation damages offer "the measure of damages most likely to reimburse plaintiff" for individual acts and forbearance, including "gains prevented" by rehance); Goetz \& Scott, supra note 4, at 1284 (finding expectation damages "good proxy" for reliance losses). Conversely, there are cases in which the reliance measure of damages is the best approximation of the parties' expectations. This is the case, for example, when a promise to hire an employee on a terminable-at-will basis is breached: "Since . . . the prospective employment might have been terminated at any time, the measure of damages is not so much what he would have earned from respondent as what he lost in quitting the job he held and in declining . . . other offer[s] of employment elsewhere." Grouse v. Group Health Plan, Inc., 306 N.W.2d 114, 116 (Minn. 1981); see also Ravelo v. County of Hawaii, 66 Hawaii 194, 658 P.2d 883 (1983) (reaching similar result in public employment context).

${ }^{25}$ See, e.g., Litman v. Massachusetts Mut. Life Ins. Co., 739 F.2d 1549, 1559 (11th Cir. 1984) (awarding $\$ 2,000,234$ in damages for profits lost as result of termination of insurance agency agreement); Walters v. Marathon Oil Co., 642 F.2d 1098, 1100-01 (7th Cir. 1981) (granting \$22,200 damage award for lost profits, where expenditures in reliance increased 
table remedies, such as specific performance or injunctive relief, in cases decided on a promissory estoppel theory. ${ }^{26}$

Our fourth and most important finding is the diminished role of reliance in determining liability. The essential requirement for liability on a promissory estoppel theory has traditionally been some specific action in justifiable reliance on the promise. ${ }^{27}$ This requirement of an identifiable detriment no longer defines the boundary of enforceability.

Perhaps the best example of a court applying promissory estoppel where the presence of clear and substantial detrimental reliance is doubtful at best is Vastoler $v$. American Can Co. ${ }^{28}$ Solomon Vastoler worked for American Can for several periods between 1937 and 1978, when he retired with a pension. He had worked as an hourly employee from 1937 to 1946, from 1947 to 1952, and from 1958 to 1963 . He was promoted to a salaried supervisory position in 1963. Vastoler was reluctant to accept the promotion because " from a financial standpoint of view, initially, he [Vastoler] was not benefitting by this promotion." "29 Vastoler testified that he told the plant manager that the promotion would leave him worse off financially, and that he would only accept the promotion

present value of real estate and thus arguably did not constitute losses); Signal Hill Aviation Co. v. Stroppe, 96 Cal. App. 3d 627, 158 Cal. Rptr. 178 (Ct. App. 1979) (granting $\$ 75,000$ in lost profit damages where $\$ 15,000$ expenses incurred in rehance); Farm Crop Energy, Inc. v. Old Nat'l Bank, 38 Wash. App. 50, 685 P.2d 1097, 1102 (Ct. App. 1984) (granting $\$ 295,000$ for lost profits, where $\$ 175,000$ expended in rehance on promise).

${ }^{26}$ See, e.g., Mazer v. Jackson Ins. Agency, 340 So. 2d 770, 772-75 (Ala. 1976) (enjoining violation of restrictive covenant); McClatchy Newspapers v. Superior Court, 163 Cal. App. 3d 214, 209 Cal. Rptr. 598, 612-15 (Ct. App. 1984) (enforcing promise of secrecy by sealing grand jury testimony); Larahee v. Booth, 463 N.E.2d 487 (Ind. Ct. App. 1984) (granting specific performance of promise to convey land); Southwest Water Servs., Inc. v. Cope, 531 S.W.2d 873, 877 (Tex. Civ. App. 1975) (enjoining increase in water rates); Remilong v. Crolla, 576 P.2d 461, 465 (Wyo. 1978) (granting imjunction to enforce restrictive covenant). Jay Feinman noted this trend in his review of the cases. See Feinman, supra note 5, at 68788.

${ }^{27}$ The first Restatement required that a promise "induce action or forbearance of a definite and substantial character." REsTATEMENT $\$ 90$. The second Restatement dropped this characterization from the text of section 90 , but stated elsewhere that satisfaction of the requirement that enforcement be necessary to avoid injustice might depend, among other things, on the "definite and substantial character" of the reliance. RESTATEMENT (SECoND) $\$ 90$ comment $\mathrm{b}$. It is, of course, difficult to arrive at standards for determining whether reliance is substantial and definite. See 1A A. CorBin, supra note $3, \S 200$, at 216-17 (defining "substantial"); id. at 218 (defining "definite"); E. FARNSwORTH, supra note 3, \$ 2.19, at 93-94 n.29 (noting that uncertainties remain as to whether cases "in which mixed motives are involved or the reliance is not entirely detrimental" may be said to involve reliance "of a definite and substantial character").

28700 F.2d 916 (3d Cir. 1983).

29 Id. at 917 (quoting memorandum of plant manager). 
if the company agreed to alter the terms of its pension plan in his favor. According to the express terms of the pension plan, Vastoler's resignation in 1952 meant that his time of service was to be measured from 1958 rather than from 1937; Vastoler claimed that the company promised him credit for his pre-1958 years of service in order to convince him to accept the promotion..$^{30}$ When the company refused to calculate Vastoler's pension benefits on the basis of the longer term of service, he sued to recover on a promissory estoppel theory. ${ }^{31}$ Vastoler claimed that he altered his position to his detriment by accepting the promotion and that justice required enforcement of the promise. ${ }^{32}$

The trial court granted summary judgment against Vastoler on the promissory estoppel claim, stating that " "nothing at all has been shown to indicate such a disadvantage to him ... by accepting the transfer as to make it imperative that the promise be adhered to in order to avoid obvious and manifest injustice." ",33 The appellate court reversed. The court admitted that, despite Vastoler's fears to the contrary, the financial package and job security he received as a salaried supervisor were better than what he would have received as an hourly employee. But the district court was faulted for viewing these financial outcomes as determinative of lack of detrimental reliance.

The appellate court first suggested that the comparison between the financial situation of a salaried supervisor and that of an hourly employee of the same company was an erroneous basis for determining lack of detrimental reliance. "The American job market is broader than American Can Company, and this was especially true during the great economic expansion of the 1960's."34 The court appeared further to suggest that Vastoler's ultimate economic position was not relevant to the inquiry because it was

${ }^{30} I d$. at $917-20$.

31 Vastoler also claimed that the terms of the pension plan mandated past service credit from 1937 rather than from 1958. This claim was rejected by both the district and the appellate courts. Id. at 918 . It is noteworthy, however, that Vastoler could have argued that a bargain was made through his negotiations with the plant manager. The appellate court stated tbat " $[t]$ he record shows . . . that Vastoler accepted the promotion, a transfer that was apparently desired more by the Company than by Vastoler, in exchange for the full recognition of his past service." Id. at 920 (emphasis added). Vastoler, then, may be an example of the use of promissory estoppel instead of traditional contract doctrine in the context of a bargaining transaction. See supra note 19 and accompanying text.

32 The district court's statement of his claim, quoted in $700 \mathrm{~F} .2 \mathrm{~d}$ at 918 , closely parallels the language of RESTATEMENT (SEcond) $\$ 90$.

s3 700 F.2d at 918 (quoting decision of district court).

34 Id. at 919. 
"merely a matter of coincidence that over the years Vastoler's financial benefits may have equalled or bettered those he would have earned had he not accepted the promotion to supervisor. Reliance is measured by the terms of the agreement, not by benefits extraneous, albeit incidental, to the agreement."35

Second, the appellate court criticized the district court for failing "to consider the human dynamics and anxieties inherent in supervisory positions." ${ }^{36}$ Even apart from any financial detriment, the court found sufficient detrimental reliance to support a promissory estoppel claim in "the stress and emotional trauma" may accompany supervisory responsibilities.

Vastoler is an instance of a court straining to find detrimental reliance in order to enforce a promise. So far as the record indicates, Vastoler's sole objection to promotion was financial, and his financial position was in fact improved as a result of the promotion. The court's suggestion that failure to gain the benefit of the promise might constitute the detriment required for recovery on a promissory estoppel theory, even if the plaintiff's cliange in position is to his financial benefit, indicates that detrimental reliance has veered far from its traditional meaning. Enforcement of a promise appears to be desired for its own sake, rather than because "justice" so requires in light of the peculiar situation of a particular plaintiff. And if psychological factors are sufficient to support a claim of promissory estoppel, relatively few promises will fail to qualify for enforcement.

A similar result was reached in Oates $v$. Teamsters Affiliates Pension Plan. ${ }^{38}$ The plaintiff, Raymond Oates, had worked for the Seafarers International Union, a competitor of the International Brotherhood of Teamsters. Oates had organized the United Industrial Workers (SIU/UIW) as a division of the Seafarers. James Hoffa, then president of the Teamsters, approached Oates in 1961 and urged him to switch unions and to bring the members of the

35 Id. at 920 . The court went on to say, however, that Vastoler's ultimate financial position might be relevant: "Whether the compensation he received during those intervening fifteen years was sufficient to substitute for the original promise so as to eliminate detriment is a question for the trier of fact." Id. The court's ambiguity on this point was noted by Judge Becker in a concurring opinion, where he stated his view that the majority opinion "is not to be construed as holding that the failure of appellee to award pension benefits based upon continuous service (the alleged promise upon which appellant sued) can itself be the substantial detriment required to trigger the doctrine of promissory estoppel." Id. at 920 (Becker, J., concurring).

${ }^{38}$ Id. at 919.

sz Id. No evidence of such emotional detriment appears to have been on the record.

38 482 F. Supp. 481 (D.D.C. 1979). 
SIU/UIW with him. At the time of this conversation neither union had a pension plan. But the Teamsters were drafting one, and Hoffa promised Oates credit for his years of service with the Seafarers in calculating his Teamsters pension. Oates joined the Teamsters, leading to a "mass exodus of officers and rank-and-file from SIU" "to a new Teamsters local. ${ }^{39}$ When Oates retired, the Teamsters denied him pension benefits. The court granted full performance of the promise on a promissory estoppel theory. ${ }^{40}$

The Teamsters claimed that promissory estoppel was an inappropriate basis for recovery since "Oates did not detrimentally rely on Hoffa's promise because the SIU did not have a pension [plan] at the time Hoffa made the promise."41 The court rejected the Teamsters' position:

There is no case law supporting Defendants' concept of detrimental reliance. Courts do not compare a party's past options with his action to determine detriment. Rather, when the promise is for future performance (as it was in the instant case) the detriment is suffered when the actions desired are performed. Oates' detrimental reliance became manifest when [the new Teamsters local] was created. ${ }^{42}$

In Oates, as in Vastoler, the court adopted a definition of detrimental reliance that permits enforcement of promises on a promissory estoppel theory even when the plaintiff's action does not substantially worsen his position. More significantly, both courts suggested that the comparison between the promissee's position before and after taking action in reliance on the promise is irrelevant to the inquiry. It is the mere taking of action that is defined in Oates as detrimental reliance. Thus, the theory of promissory estoppel put forth in Oates has as much in common with traditional contract doctrine as it does with detrimental reliance as a basis for recovery. ${ }^{43}$ In these cases, promissory estoppel has ex-

30 Id. at 483 n.2 (quoting Teamsters' statement printed in the Philadelphia Inquirer, Feb. 2, 1962, and the N.Y. Times, Feb. 3, 1962).

10 In denying the pension benefits, the Teamsters interpreted the terms of the pension plan as not extending benefits to one in Oates' position. The court rejected this interpretation, finding instead that Oates came within the plan's provision for crediting prior service " "with any labor organization prior to the . . . affiliation with IBT of all or a substantial part of its membership.' " 482 F. Supp. at 484 (quoting 1962 plan). The court nonetheless relied on promissory estoppel rather than a traditional contract theory of enforcement, thereby avoiding the need to determine Oates' length of service with SIU/UIW. Id. at 486 .

11 Id. at 489 (footnote omitted).

42 Id.

43 For the observation that promissory estoppel is often applied in the context of bar- 
panded beyond its traditional function of protecting a promisee who has changed his or her position for the worse as a result of the promise. ${ }^{44}$

\section{B. The Scope of the Expansion}

Admittedly, the expansion of promissory estoppel beyond detrimental reliance has not been smooth. Some uncertainty and apparent contradiction still appear in the cases. We do not claim that all the cases can be reconciled with the conclusion that detrimental reliance is no longer the key to promissory estoppel. But we believe that much of the dissonance is the result of courts using the language of reliance to take account of three factors which quite correctly tip the balance in favor of recovery: (1) the presence of a credible promise; (2) the promisor's authority to make the promise; and (3) the existence of a benefit to the promisor from economic activity. These factors do more than account for inconsistencies in the reported cases. They also define the limits of an emerging theory of contractual obligation.

1. The Presence of a Credible Promise. Promise-making is the linchpin of liability under both traditional contract doctrine and promissory estoppel. The requirement of a promise makes liability turn on the voluntary assumption of duty, and thus underlies the function of contract law as a promoter of voluntary agree-

gain transactions, see Henderson, supra note 19, at 345-50.

The concepts of "detriment" and "consideration" are, of course, historically linked. The early view of consideration defined it as benefit to the promisor or detriment to the promisee. See W. STORY, supra note 12, § 431. The stress of contemporary contract law on "bargain"- that "the same thing may be a consideration or not as it is dealt with by the parties," O. HoLmEs, supra note 12, at 292-was a later innovation. See G. GILMORE, supra note 11 , at 19-22.

44 For a case similar to Vastoler in facts and result, see Landro v. Glendenning Motorways, Inc., 625 F.2d 1344, 1355 (8th Cir. 1980).

It is relatively easy to find cases in which courts have used considerable creativity in finding sufficient reliance to serve as the basis for promissory enforcement, or in which they have failed even to raise the issue of rehance. See, e.g., Mesa Petroleum Co. v. Conigho, 629 F.2d 1022, 1027 (5th Cir. 1980) (finding reliance by plaintiff in paying off debt on a promissory note, where plaintiff was jointly obligated on the note); Christensen v. Minneapohis Mun. Employees Retirement Bd., 331 N.W.2d 740, 747 (Minn. 1983) (enforcing commitment to provide a pension, where no specific reliance shown); Dulany Foods, Inc. v. Ayers, 220 Va. 502, 590-11, 260 S.E.2d 196, 200-02 (1979) (enforcing promise to pay severance benefits; reliance found in employees' refraining from disruptive conduct on the job prior to sale of plant, and continuing to work until that time). In an earher English case in which esteppel by promise was recognized, reliance was also evanescent. See Central London Property Trust Ltd. v. High Trees House Ltd., [1947] K.B. 130, 132-33 (1946) (enforcing agreement to reduce rent "so that defendants-might be enabled to continue to run their business"; no specific acts of reliance shown beyond having stayed in business). 
ments. But courts have long had trouble distinguishing binding commitments from other communications such as opinions, predictions, or negotiations. ${ }^{45}$

This issue has not disappeared in the modern cases. If anything, it is even more likely to arise with the relatively informal statements that often form the basis of promissory estoppel claims. ${ }^{46}$ The less formal the parties' actions, the greater must be the court's attention to their context. Focusing on the issue of whether a promise has been made explains the differing results in some otherwise superficially similar cases.

In Garcia $v$. Von Micsky, ${ }^{47}$ for example, a patient had a tubal ligation and was told by the operating physician several months later that "she had nothing to worry about, that it was impossible for her . . . to have any more children."48 Within a year she became pregnant, but the court affirmed dismissal of the complaint as involving a mere "therapeutic reassurance." 49 The characterization of the physician's statement as an assurance rather than as a promise was by no means necessitated by his choice of words. Rather, the court appears to have been influenced in part by the fact that the statement "was made long after he completed his surgery and that it was not part of another contractual arrange-

4 Courts often resort to conclusory language in finding that a inanifestation rises to the level of a promise. This is not surprising. Judges called upon to determine whether a promise has been made must look beyond the words and acts which constitute the transaction to the nature of the relationship between the parties and the circumstances surrounding their actions. But relationships and surrounding circumstances do not speak for themselves. They must he interpreted by judges on the basis of the expectations likely to arise between similarly situated parties. The conclusory tone follows because we are being told what we ought already to understand as members of the community. It is inherent in the use of an objective standard-under both traditional contract and promissory estoppel theories of obligation-to determine whether a commitment was voluntarily made.

46 For cases deciding that no promise was made, see, e.g., A \& M Fix-It, Inc. v. Schwinn Bicycle Co., 494 F. Supp. 175, 178 (D. Utah 1980) (finding that failure to advise plaintiff that proposed new location was unacceptable was not promise to continue franchise after plaintiff's move to that location); Allen v. Atlantic Richfield Retirement Plan, 480 F. Supp. 848, 850-51 (E.D. Pa. 1979) (holding that clear statement in handbook about pension filing deadline refuted claim that handbook description of advisory role of employee relations representative constituted promise of warning froin representative about filing deadline), aff'd mem., 633 F.2d 209 (3d Cir. 1980); McCroskey v. State, 8 Ohio St. 3d 29, 30-32, 456 N.E.2d 1204, 1205-06 (1983) (finding preliminary lease terms and letter of intent to be mere preliuninary negotiations). For cases concentrating on uncertainty in the terms of the alleged promise, see, e.g., Weisberg v. United States Dep't of Justice, 745 F.2d 1476, 1494 (D.C. Cir. 1984); Santoni v. FDIC, 677 F.2d 174, 179 (1st Cir. 1982); Keil v. Glacier Park, Inc., 188 Mont. 455, 462-64, 614 P.2d 502, 506-07 (1980).

47602 F.2d 51 (2d Cir. 1979).

4 Id. at 52.

19 Id. at 53. 
ment." assure the patient, rather than to induce any action on her part. Given the common understanding that physicians generally do not give warranties; the court's conclusion was correct. ${ }^{51}$

In Burst v. Adolph Coors Co., ${ }^{52}$ plaintiff's promissory estoppel claim was premised on "Selection Guidelines" in a pamphlet given to franchise applicants. After several interviews, plaintiff's application was rejected, along with all other applications still outstanding. Coors explained that it had decided to liandle distribution in the area througll a wholly owned subsidiary until a suitable distributor was found. The guidehines, though several times mentioning tlie expectation of appointing the best qualified candidate, contained only one express commitment, namely, to "give each applicant fair and equal consideration." dant's motion for summary judgment after concluding that " $[\mathrm{i}] \mathrm{t}$ does not comport with reason that defendant would commit itself in all events to appoint one of the applicants as its distributor, considering what was at stake for defendant." 54

Similar results have been reached in the employment context. In Campbell v. Sirak, the court rejected a claim that the promise by a university of a "courtesy rank" amounted to a promise of tenure or other job security. The plaintiff was found to be too familiar with academic procedures to have reasonably sustained a contrary expectation.

Problems of interpretation are greatest when the required

so Id. at 52.

s1 The earher case of Hawkins v. McGee, 84 N.H. 114, 146 A. 641 (1929), helps to illustrate the significance of the ahsence of a special contractual arrangement. In Hawkins, a surgeon embarking upon an operation to graft skin onto his patient's hand was held to have warranted " 'to make the hand a hundred per cent perfect hand' or 'a hundred per cent good hand." "Id. at 115, $146 \mathrm{~A}$. at 643 (quoting statement of physician as stated in testimony). The surgeon argued that, whatever his words, "common knowledge of the uncertainty which attends all surgical operations,' and the improbability that a surgeon would ever contract to make a damaged part of the human body "one hundred per cent perfect," meant that he could not reasonably be understood to have guaranteed perfection. Id. at 116, $146 \mathrm{~A}$. at 643 (quoting contention of physician). The court concluded that it did not have to reach this question because of "countervailing considerations"-evidence that "the defendant repeatedly solicited from the plaintiff's father the opportunity to perform this operation." Id. Active solicitation was hikely seen as falling beyond the expected boundaries of the surgeon's role, and therefore supported the conclusion that the surgeon gave an extraordinary guarantee.

${ }_{52} 503$ F. Supp. 19 (E.D. Mo. 1980), aff'd, 650 F.2d 930 (8th Cir. 1981).

s3 Id. at 21 (quoting defendant's "Basic Distributor Selection Guidelines").

st Id. at 22-23.

ss 476 F. Supp. 21, 29-32 (S.D. Ohio 1979), aff'd mem. sub nom. Campbell v. Board of Trustees, 705 F.2d 451 (6th Cir. 1982). 
promise is inferred partly or wholly from conduct. In Wachovia Bank \& Trust Company, N.A. v. Rubish, ${ }^{\mathrm{s}}$ a commercial lease for a ten-year period granted the lessee an option to extend the lease for six additional five-year periods upon written notice. The landlord had twice extended the lease on oral notice. When the landlord died, his trustee informed the tenant that the lease had been terminated for failure to give written notice of his intention to extend. The North Carohna Supreme Court held that the landlord "had waived two breaches of the condition of written notice, and defendant had relied on the promise implied from these waivers that no written notice would be thereafter required."sz

Rubish may be an extreme example of judicial willingness to imply a promise from a course of conduct. Other courts have been more circumspect. ${ }^{58}$ In Division of Labor Law Enforcement $v$. Transpacific Transportation Co., ${ }^{59}$ for example, the court rejected the claim that a promise to pay Christmas bonuses should be implied from an employer's fifteen-year uninterrupted practice of paying such bonuses. The court noted testimony that while the practice of paying bonuses was mentioned in pre-employment interviews, potential employees were made aware that "the payment of future bonuses was conditional, uncertain and there was absolutely no guarantee with regard to any future bonuses."60 Denyimg enforcement in such a case is reasonable; were judicial recognition not given to express disclaimers of intent to promise, the voluntary nature of promise-making would be seriously undermined.

2. The Promisor's Authority to Make the Promise. The person making an otherwise actionable promise sometimes lacks the authority to bind the organization involved and cannot reasonably be understood to have such authority. The expansive scope and hierarchy of modern enterprise makes such limitations on authority unavoidable. Because agency law has all but disappeared as a separate legal discipline, attorneys, judges, and law clerks are illequipped to perceive agency issues. Often opinions refer to a lack

se 306 N.C. 417,293 S.E. 2 d 749 (1982).

${ }^{57}$ Id. at 429,293 S.E.2d at 757.

ss Compare Everett v. Brown, 321 S.E.2d 685, 688-90 (W. Va. 1984) (applying promissory estoppel to defeat statute of frauds defense, where real estate owner permitted broker to show property after expiration of written listing agreement), with Landess v. Borden, Inc., 667 F.2d 628, 632-33 (7th Cir. 1981) (refusing to infer promise to continue plaintiff's hauling contract in perpetuity on the basis of three years of service, despite defendant's knowledge of plaintiff's purchase of new truck).

so 69 Cal. App. 3d 268, 137 Cal. Rptr. 855 (Ct. App. 1977).

so Id. at 276,137 Cal. Rptr. at 860 . 
of reasonable reliance in cases in which the reliance is unreasonable largely because of the promisor's evident lack of authority. ${ }^{61}$

In Reamer $v$. United States, ${ }^{62}$ a law student who enlisted in the army alleged that his recruiters promised him a semester delay in starting active service. Reamer signed a long printed contract which included a disclaimer of any ancillary promises. He also signed an "acknowledgment of understanding" that said he would begin active duty within 120 days of signing unless a delay for a longer period "is authorized or directed by the Department of the Army." "B3 But his signed contract included the following typed statement: "Delayed from entry on ACDUTRA or active duty until 1 Feb. 69." 64 This statement, which the recruiters typed into the contract before Reamer signed it, formed the basis of plaintiff's claims of breach of contract and promissory estoppel after the Army called him to duty during before the specified date, which marked the end of his semester.

In the course of its decision, the court discussed the apphication of agency principles to Reamer's claims:

The acknowledgment specifically requires that the authorization come from the Department of the Army. Although Wall and Dominick had the authority to bind the military to enlistment contracts, the words of the acknowledgment signify that a delay for more than 120 days is not routinely part of an enlistment contract and that special permission from a higher authority is required. . . . Thus, the words of the contract do not indicate that the Department of the Army authorized the delay .... . ${ }^{65}$

61 The issue of authority to make a promise frequently arises in the context of promissory estoppel claims against the federal government. Promissory estoppel does not apply as broadly against the federal government as it does against private actors. McCauley v. Thygerson, 732 F.2d 978, 980-81 (D.C. Cir. 1984). But cf. Christensen v. Minneapolis Mun. Employees Retirement Bd., 331 N.W.2d 740, 749 (Minn. 1983) (involving state government: "Promissory estoppel, like equitable estoppel, may be applied against the state to the extent that justice requires."). Federal contracts are often governed by statutes and regulations, and "[p]romises . . . that contravene or otherwise exceed terms specified in statutes or regulations will not in most cases bind the federal government unless the federal official making the promise acted within the scope of his or her authority in doing so." McCauley, 732 F.2d at 981 . Principles of sovereign immunity also serve to distinguish the position of public and private-sector defendants in promissory estoppel cases. See Jablon v. United States, 657 F.2d 1064, 1067-70 (9th Cir. 1981).

${ }^{62} 532$ F.2d 349 (4th Cir. 1976).

cs Id. at 351 .

64 Id. at 350 .

es Id. at 351-52. 
Thus, Reamer was expressly notified that the recruiters lacked the authority to bind the Army with respect to the promise.

This lack of authority should have been enough to decide the case. ${ }^{66}$ Curiously, however, the court relied on lack of authority only to find an inconsistency between the written contract and the acknowledgment form, creating an ambiguity which could then be resolved by parole evidence. Parole evidence indicated that the plaintiff "had been twice told that permission for the delay must come from higher authorities." ${ }^{67}$ Hence, the court concluded, there was no promise and any reliance by the plaintiff was unreasonable. The court seems not to have realized that, quite apart from any question of rehance or contract interpretation, a contract or promise made without actual or apparent authority is not binding.

The Reamer court did at least identify authority as an issue. Other courts have failed to do so, even though agency principles would have provided a more suitable basis for determining whether the promise should be enforced. For example, in Ryan v. J.C. Penney $\mathrm{Co}_{.,{ }^{68}}$ a retail clerk employed by a branch of a national chain of department stores claimed that her discharge violated the promises of her department manager and of the branch's personnel manager not to discharge her except for just cause. Reversing the trial court, the Seventh Circuit granted defendant's motion for summary judgment. Absent evidence to the contrary, the court reached the correct result in refusing to enforce the promise. It is doubtful that local personnel had actual authority to grant life tenure or that an employee could reasonably believe that such authority existed.

In contrast, in MacEdward v. Northern Electric Co., ${ }^{69}$ a company's fiight director sought enforcement of the company president's promise to give him an employment contract for "two,

66 In Reamer, the recruiters had neither actual nor apparent authority to delay enlistment heyond 120 days. Actual authority would turn on the manifestations between the principal and the agent, here the Army and its recruiters. See REsTarement (SECond) or AGENCY $§ 7$ (1958). The Reamer court noted that "[t]he plaintiff does not contend that the two officers had the actual authority to grant . . . permission" to delay active duty. $532 \mathrm{~F} .2 \mathrm{~d}$ at 351-52. Apparent authority, on the other hand, is based upon the representations made by the principal to the third party. See Restatement (SECOND) of Agency § 8. "[U]ntrue representations by an agent as to the existence or extent of his authority or the facts upon which it depends" do not subject a principal to habihty. Id. $\$ 168$ (emphasis added). In Reamer, the only representations from the Department of the Army to Reamer were in the enlistment contract itself, which provided that the Department must authorize or direct delays of longer than 120 days. 532 F.2d at 351 . No such authorization was given.

632 F.2d at 352 .

68 627 F.2d 836 (7th Cir. 1980).

${ }^{69} 595$ F.2d 105 (2d Cir. 1979). 
three, or five years or at least a gentlemen's agreement."70 This situation is more compelling because the employee's claim was based on representations made by the president of the company, who is a more powerful agent, and on an alleged contract for a fixed term with a minimum of two years, which is a more common contractual arrangement. The appropriate result in a case like MacEdward is to enforce the promise: a company president's authority to grant such a contract is well beyond doubt.

3. The Importance of Benefit to the Promisor from Economic Activity. As we have seen, courts have manipulated the reliance concept to find liability in a number of promissory estoppel cases. A fuller understanding of this expansion of promissory hability can be gained through an examination of the way in which courts have strained traditional bargain concepts in similar factual settings.

Pine River State Bank v. Mettille ${ }^{71}$ exemplifies this expansion of the bargain concept. In Pine River, an at-will employee was discharged without benefit of the procedural safeguards laid out in an employee handbook distributed while he was an employee. The trial court found for the employee on grounds of breach of contract. On appeal, the employer argued that the handbook could not be considered a modification of the terms of the at-will employment contract because no consideration existed for the handbook's increased job security protections. Under traditional contract theory this argument carries much force. The job security provisions were not bargained for; no identifiable exchange from the employee was specified. ${ }^{72}$ The Minnesota Supreme Court affirmed, however, finding that the handbook was an offer of a unilateral contract and that the employee's "continued performance despite his freedom to leave" constituted both acceptance and consideration.

Use of the unilateral contract device to enforce one-sided modifications of ongoing relationships has found increasing favor. ${ }^{74}$

70 $I d$. at 106.

71333 N.W.2d 622 (Minn. 1983).

72 See generally Pettit, Modern Unilateral Contracts, 63 B.U.L. REv. 551, 559-67 (1983).

${ }^{73} 333$ N.W.2d at 629. Accord Woolley v. Hoffman-LaRoche, Inc., 99 N.J. 284, 302, 491 A.2d 1257, 1267 (1985) ("[T] contract-the employees' bargained-for action needed to make the offer binding being their continued work when they have no obligation to continue.").

74 See, e.g., Becker v. Missouri Dep't of Social Servs., 689 F.2d 763, 766-67 (8th Cir. 1982) (interpreting promise to rehire employee as a unilateral contract); Thompson v. St. Regis Paper Co., 102 Wash. 2d 219, 228-31, 685 P.2d 1081, 1087-88 (1984) (interpreting 
Technically, however, plaintiffs in such cases receive a windfall, for the change in terms is not bargained for and does not require any additional commitment from or detriment to them. In Pine River, the employer clearly anticipated some benefits from improved procedural safeguards, but specified no clearly defined conduct by the worker as the price of the new benefits. Workers clearly were not buying the benefits by promising to work for any specified period. Nor was there any understanding that the promised rights would vest only after some period of additional work. A court might hold that simply showing up for work the next day was the bargainedfor exchange. But is this really true to the intent of the parties? Nothing in the handbook suggested that the new benefits were a bonus simply for showing up for work the day after the handbook came out, nor would the employer want the employee to think that so little was expected in return.

The employer typically does expect benefits from such arrangements, such as obtaining lower turnover or keeping out a union. But while "inferences of reciprocity can be drawn" when these understandings are reached, it distorts the facts to say that anything specific has been exchanged. Judges do construct conventional contracts in such cases, but only a Cardozo could make them seem plausible. ${ }^{76}$ Nonetheless, such judicial creativity represents a recognition that the promises in such cases are not gratuitous in the ordinary sense of the word. ${ }^{77}$

The expansion of the notion of consideration in cases like Pine River to enforce promises that are neither bargained for nor gratuitous closely parallels the expansion of detrimental reliance in cases

policies in employee manual as unilateral contract). See generally Pettit, supra note 72, at 559-67 (citing cases).

${ }^{73}$ Goetz \& Scott, supra note 4, at 1308.

78 For examples of Judge Cardozo's creative ability to find enforceable promises, see Wood v. Lucy, Lady Duff-Gordon, 222 N.Y. 88, 118 N.E. 214 (1917) (employment agreement); De Cicco v. Schweizer, 221 N.Y. 431, 117 N.E. 807 (1917) (marriage settlement). Cardozo's influence on breaking down the Holmesian theory of contract is discussed in G. GiLmore, supra note 11, at 57.

77 The reality that some promises have non-quantifiable yet tangible economic benefits is not lost on judges. See Toussaint v. Blue Cross \& Blue Shield, 408 Mich. 579, 613, 292 N.W.2d 880, 892 (1980) ("The employer secures an orderly, cooperative and loyal work force ... . It is enough that the employer chooses, presumably in its own interest, to create [such] an environment . . . . The employer has then created a situation 'instinct with an obligation.' ") (quoting Cardozo's opinion in Wood v. Lucy, Lady Duff-Gordon, 222 N.Y. 88, 91, 118 N.E. 214, 214 (1917)); Thompson v. St. Regis Paper Co., 102 Wash. 2d 219, 229-30, 685 P.2d 1081, 1087 (1984) (employers make promises in manuals "to create an atmosphere of fair treatment and job security"). 
like Vastoler. ${ }^{78}$ It is not surprising to find courts imposing liability when the defendant has made a promise in the expectation of receiving an economic benefit from the plaintiff. Quite apart from any unjust enrichment which might have resulted from the promise, breach of a promise seems especially unjust when the promisor was willing to reap economic benefits from the promise but not to pay the price. The simple idea that one must "accept the bitter with the sweet" is a core intuition underlying these cases. Similarly, the absence of a prospect of benefit to the promisor from economic activity argues against enforceability. Our survey of the promissory estoppel cases suggests that courts have been responsive to the presence or absence of such a benefit from economic activity.

Two insurance cases that have been identified by one commentator as exemplifying the inadequacy of current applications of promissory estoppel ${ }^{79}$ serve instead to demonstrate the consistent apphication of the "economic activity" test. In Prudential Insurance Co. of America v. Clark, ${ }^{80}$ an insurance company sought the return of hife insurance proceeds paid to the beneficiaries of a Vietnam serviceman, Clark. Another insurance company had issued Clark a life insurance policy without war risk or aviation exclusion clauses. A representative of Prudential contacted Clark and urged him to replace his policy with a Prudential policy. The Prudential agent advised Clark that Prudential would also issue a policy without the exclusion clauses. Nevertheless, the policy was issued with these clauses. Unaware of this fact, Clark cancelled his original policy. He was later killed in Vietnam. The representative wrote a memorandum to Prudential urging payment of the claim filed by Clark's beneficiaries despite the exclusion clauses. The claim was paid, but the home office later demanded repayment.

Although no contract was formed, the court held the promise to issue a policy without exclusion clauses enforceable. ${ }^{81}$ The court's opinion focused on economic benefit to Prudential: "Prudential's act of payment . . . recognized its duty to honor [its agent's] action, which had enriched the company"82 by inducing Clark to drop his original pohicy and to enter into a business rela-

${ }_{78}$ Vastoler v. American Can Co., 700 F.2d 916 (3d Cir. 1983), discussed supra text accompanying notes 28-37.

${ }^{70}$ See Feinman, supra note 5, at 701-07.

so 456 F.2d 932 (5th Cir. 1972).

81 Id. at 936.

s2 Id. at 937 . 
tionship with Prudential.

In contrast, Marker $v$. Preferred Life Insurance $\mathrm{Co}^{83}$ denied enforcement against an insurance company of a promise by its representative. Marker was engaged in negotiations to purchase property that the seller had insured with Johnson, an agent for Preferred Life. The seller suggested to Marker that he have Johnson look at the purchase contract. In the course of their discussion, Marker informed Johnson that he would not renew the insurance policy with Johnson. Both Marker and his father were Preferred Life agents, and Marker stated that he or his father would write the renewal policy. Nonetheless, Marker asked Johnson to inform him when the policy was about to expire, and Johnson agreed to do so. But Johnson neglected to notify Marker, the policy lapsed, and the property was damaged by a tornado. ${ }^{84}$

Marker sued Preferred Life for damages resulting from Johnson's failure to notify. The court rejected Marker's promissory estoppel claim. ${ }^{85}$ In denying enforcement, the court noted the parties' expectations of reliance. "The evidence falls far short of showing that Johnson intended or expected Marker to rely upon the promise ... . The promise of Johnson to advise Marker of the expiration date of the policy was a promise wholly without consideration and essentially was made as a mere accommodation to Marker."86 Elsewhere the court observed that the promise was not made in furtherance of any anticipated broker-client relationship, nor had any such relationship ever existed between the parties. ${ }^{87}$ Hence, there was no expectation of a commission or other benefit to Johnson, who was inerely a friend and business advisor of the seller of the land.

The essence of the Marker decision, obfuscated by the reliance analysis, is that the promise was not made in furtherance of any economic relationship or activity. The defendant in Marker was not making a promise to a prospective client (or even to someone likely to steer business his way in the future) since the plaintiff's father was also an agent with the same company. The defendant neither sought nor saw a prospective benefit or ongoing relationship, and none was offered by the plaintiff. Under these circum-

ss 211 Kan. 427, 506 P.2d 1163 (1973).

Bt Id. at 428-31, 506 P.2d at 1166-67.

as Id. at $434-35,506$ P.2d at 1170 .

s6 Id. at 435,506 P.2d at 1170 .

87 Id. at 433, 506 P.2d at 1169. This finding also suggests that Johnson was not acting in his capacity as a Preferred Life broker, thus indicating a possible agency defense. See generally supra text accompanying notes 61-70. 
stances, where the promise is not related to current or prospective activity between the parties, nonenforcement appears reasonable. In Clark, on the other hand, the promise was made to obtain a new insurance customer. Traditional promissory estoppel analysis obscures the decisive distinction between these two cases, namely, benefit to the promisor. ${ }^{88}$

${ }^{88}$ Two other cases demonstrate how the nature of the economic relationship between the parties affects the enforceability of promises made in the course of that relationship. In Mills v. Merrill Lynch, Pierce, Fenner \& Smith, Inc., 703 F.2d 305 (8th Cir. 1983), Mills, a commodity customer of Merrill Lynch, disputed a margin call which resulted in the liquidation of his account. Merrill Lynch later credited him with the difference between the value of his account when liquidated and its value when it was reestablished. Reimbursement was to take the form of commission credits on future trades. Approximately one-quarter of the total amount to be reimbursed had been credited when Mills severed ties with Merrill Lynch. Merrill Lynch refused to pay the remainder owed, claiming that it was not contractually obligated to do so. Mills sued based on contract and promissory estoppel. The Eighth Circuit found that no contract existed, rejecting Mills' contention that his forbearance from suing Merrill Lynch was consideration for Merrill Lynch's promise. Id. at 307. Neither, the court found, did Mills detrimentally rely on the promise by faihing to sue. Id. at 308 . In our view, the court's resolution of the reliance issue was weak: it is unlikely that Mills would have simply done nothing to recapture a $\$ 23,313$ loss had no promise been made. But the result can be justified under our economic-activity test. By choosing to reimburse Mills on the basis of credits on future trades, Merrill Lynch might well have intended, and have been Imderstood to have intended, to enhance its future business relationship with Mills through payments made on the basis of the volume of future business. The basis for the intended economic benefit ended when Mills himself terminated the account.

It would be a mistake, however, to assume that the termination of the promisor's relationship with the promisee always supports the conclusion that a promise should not be enforced. In a case like Femberg v. Pfeiffer Co., 322 S.W.2d 163 (Mo. Ct. App. 1959), where a pension is awarded for previous service, there may be numerous benefits that a company may wish to obtain despite the fact that the individual employee is retiring and thus offers no prospect of future direct benefit to the company. The employer may be making a record for other employees to see, expecting to enhance good will and productivity in the office. The fact that the announcement of the intention to grant a pension to Mrs. Feinberg was made in a formal resolution of the Board of Directors that recited her long and loyal service as justification, lends credence to the conclusion that other einployees were expected to take note of the connection between loyalty and benefits. The court did not, however, base recovery on this theory.

Cases like Feinberg suggest that the concept of economic benefit to the promisor must be broad enough to include situations in which the prospective benefits are expected to derive from the reactions of persons other than the promisee. The potentially bormdless sweep of such a concept can be checked by requiring a close examination of the manifestations constituting the promise. Private negotiations, like those in Mills, are less likely to support the enforcement of a promise on these grounds than are formal statements like that in Feinberg.

For examples of promises not made to further econoinic activity and thus properly held nonenforceable under promissory estoppel theory, see Ervin v. Ervin, 458 A.2d 342 (R.I. 1983) (promise by divorced husband to pay nonminor son's college expenses not enforceable because of lack of reliance); Alden v. Presley, 637 S.W.2d 862 (Tenn. 1982) (promise to pay off inortgage of girlfriend's mother not enforceable). 


\section{Redefining the Basis of Promissory Obligation}

Two factors appear to coalesce in cases in which promissory obligation has been expanded beyond its traditional boundaries. First, as suggested above, the promisor's primary motive for making the promise is typically to obtain an economic benefit. Second, the enforced promises generally occur in the context of a relationship that is or is expected to be ongoing rather than in the context of a discrete transaction. These relationships are characterized by a need for a high level of mutual confidence and trust.

A. Economic Benefit in Ongoing Relationships: Closing the Relational Gap in Contract Law

Economic motives underlie many of the kinds of employer promises which have been enforced through the expansion of promissory estoppel and unilateral contract doctrines. The employer attempts to produce employment conditions in which employees are comfortable and relatively secure in order to gain increased loyalty and productivity from them. But as cases like Pine River $^{88}$ demonstrate, the anticipated benefits cannot readily be reduced to the terms of a traditional bargain. We believe that recent expansions of promissory obligation are based upon the insight that an economic exchange need not be seen as taking place in an isolated transaction or at a specific time, nor need it be manifested by an identifiable increase in the promisor's economic assets. In the context of ongoing relationships, exchange is a continuing rather than a discrete event. ${ }^{\circ 0}$ Where such relationships are highly

89 Pine River State Bank v. Metille, 333 N.W.2d 622 (Minn. 1983), discussed supra text accompanying notes 71-74.

Do Ian Macneil lias led the attack on notions of promissory obligation that are modelled on the "paradigm [of] the transaction of neoclassical microeconomics," in which "no relation exists between the parties apart from the simple excbange of goods." I. MacnerL, Social CoNTRACT, supra note 12, at 10. For elaboration of Macneil's theory of relational contract, which le defines as "involving relations other than a discrete excliange," id., see Macneil, Values in Contract: Internal and External, 78 Nw. U.L. REv. 340 (1983); Macneil, Efficient Breach of Contract: Circles in the Sky, 68 VA. L. REv. 947 (1982); Macneil, Economic Analysis of Contractual Relations: Its Shortfalls and the Need for a "Rich Classificatory Apparatus," 75 Nw. U.L. REv. 1018 (1981); Macneil, The Many Futures of Contracts, 47 S. CAL. L. REv. 691 (1974); Macneil, Restatement (Second) of Contracts and Presentiation, 60 VA. L. REv. 589 (1974).

Macneil's scholarship lias liad an impact on the law and economics literature. See, e.g., Goetz \& Scott, Principles of Relational Contracts, 67 VA. L. REv. 1089, 1089 n.1 (1981) (citing work of Williamson, Goldberg, and others). To Goetz and Scott, "[a] contract is relational to the extent that the parties are incapable of reducing important terms of the arrangement to well-defined obligations." Id. at 1091. The difference between the approach of Goetz and Scott and that of Macneil is that Goetz and Scott limit their discussion to cases 
interdependent, economic benefit is likely to be sought through informal understandings that reinforce the relationship, rather than through discrete bargains.

Consider again the typical employee's position. An employee has a substantial investment in a job and is expected to make increased future investments. $\mathrm{He}$ or she has acquired job-specific skills, which are less valuable on the market than to the present employer. At least some of the benefits to be obtained from employment, like pensions or promotions, are not immediate. The employee faces high search costs, including the risk of a prolonged period of unemployment, if he or she decides to obtain another job. Finally, the employee's mobility may be restricted by consumption choices based on his or her employment situation, such as home ownership. Hence, the employee normally has a strong stake in the continuation and development of an ongoing relationship with the employer.

The employer has different but not wholly dissimilar needs. The employer has invested in the selection and on-the-job training of the employee, an investment that can be lost through employee turnover. Moreover, the employer cannot supervise employees closely enough to ensure that they invest their best efforts. The employer would therefore like to use an incentive system and other inducements to encourage effort. Thus, like the employee, the employer has a stake in the quality of the employment relationship.

in which formal contracts have been made; their focus is then on interpreting the terms of those contracts the better to capture the intent of the parties. Their approach accounts well for attempts to accommodate requirements contracts, exclusive dealing contracts, flexible price terms, good faith standards of performance, unilateral termination agreements, and other contract terms, express or implied, which would render contracts unenforceable in traditional terms. But the concern with building flexibility into formal contracts has long been a feature of American contract law. As Macneil has pointed out, "neoclassical" contract law, of which the Uniform Commercial Code is an example, fails because it "modif[ies] the wisdom of the law of discrete transactions, without at the same time building relational foundations." I. MacNeIL, Socral Contract, supra note 12, at 74.

Macneil's "relational foundations" are based, as are those of our approach, on trust. But our approach to relational contracts differs from Macneil's in some respects. First, Macneil applies his theory to some kinds of agreements which do not fit within our "economic activity" test. See, e.g., I. MaCNEIL, Social Contract, supra note 12, at 20 (including marriage as a "contractual relation"). Second, Macneil does not stress the existence of a promise in lis deflnition of contract. Instead, he sees promise-making as but one of several ways in which legitimate expectations arise. See, e.g., id. at 53-54; Macneil, The Many Futures of Contract, supra, at 734-35 ("contracts consist of a variety of components, of which truly communicated promise, brought to maximum present effect, is but one coequal component, and not always even that"; " 'contract' is a very useful word to describe the totality of economic exchange relations whether promises are the dominant or even a significant factor in the relation"). 
This mutual interest in a long-term and amicable relationship is part of the explanation Okun ${ }^{91}$ and Thurow ${ }^{92}$ give for the behavior of the labor market. For example, classical economics suggests that if someone were to come along and offer to perform an employee's job at a reduced rate, the employer would fire the existing employee and replace him by the lower cost employee. Yet in reality this never happens. The reason is that the employer cannot afford to take action that will discourage employees from making long-term investments in their jobs. For example, much on-the-job training is actually given by older employees, who will have hittle incentive to provide such training if they fear their own jobs may be at stake. To maximize the benefits of their relationship, both sides need a certain amount of trust.

Up until this point, relationships characterized by interdependence and thus by a need for trust have been described as though they were exceptional. This description could not be further from the truth. The network of interdependence in modern economic relations extends far beyond the ongoing relationship between specific parties to the very structure of the modern economy. ${ }^{93}$ Modern economic relations are dependent upon institutions which themselves are based on trust. The firm, an essential economic unit, can function only if employees and employer have at least limited trust in each other. Markets for goods can exist only if sellers normally can be trusted to make future deliveries of nondefective products. Insurance, credit, and investment can exist only when the other party generally can be trusted to pay.

These institutional arrangements are not only valuable to the

91 A. OKun, supra note 1, at 81-133 (describing choice of "career" labor strategy over "casual" labor strategy, with resulting need for arrangements to counter distrust in longerterm employment relationships).

${ }^{92}$ Lester Thurow, Dangerous Currents: The State of Economics 184-215 (1983) (discussing employee motivation and critiquing the "price-auction" model's disavowal of its importance).

93 This interdependence has been noted by commentators of many persuasions. In the terms of the critical legal scholar, contractual obligations "are elements of people's interaction for their collective benefit not defined by the arithmetic sum of their individual 'welfares." "Feinman, supra note 4, at 860 . In the language of law and economics, "in cooperative ventures where each party's profits are dependent on the quantity or quality of the other party's efforts, efficient exchange requires that each party pay the other to undertake the optimal level of the respective activity." Goetz \& Scott, supra note 90, at 1110.

The model of promissory liability proposed by Goetz and Scott suffers generally from its stress on "discrepancies between optimal and actual enforcement rules" rather than on "the social utility of bargains." Goetz \& Scott, supra note 4, at 1292 . We have preferred to use economics to formulate a macroscopic view of the role of contracts in modern society, rather than to analyze particular fact patterns on a microscopic basis. 
individuals involved in specific transactions. They are also valuable to society as a whole..$^{94}$ For example, risk aversion is socially inefficient. If firms must carry their own risks, some risky ventures will find no takers even though their expected returns are positive. The net social benefits from such ventures will not be realized without some form of insurance. Similarly, credit and investment allow resources to flow to entrepreneurs with valuable projects but low assets. Credit also allows the modern consumer economy to function. Forward contracting permits planning, which in turn increases the efficiency of resource use. Thus contract does not merely involve fussy rearrangements of transaction costs; ${ }^{95}$ rather, it is essential to having an economy in which things like transaction costs can exist.

Because trust is essential to our basic economic institutions, it is a public good. One individual breaking trust in a dramatic way, or many individuals breaking trust less dramatically, can lead to short-run benefits for those individuals but create negative externalities. The willingness of others to trust is impaired, requiring them to invest in precautions or insure themselves against the increased risk of betrayal. ${ }^{96}$ Such externalities exist because of asymmetrical information: the promisor necessarily has better information about his own trustworthiness than does the promisee. For example, in the short run employers can profit by making commitments to employees, obtaining the resulting benefits, and then reneging. But in the long run, enforcement benefits promisors as a group by fostering the reliance from which they seek to benefit. Conversely, trustworthy individuals confer a social benefit by increasing the general perception of trust, thereby allowing others to decrease such costs.

Seen in this light, the cases in which courts have pushed the doctrine of promissory estoppel beyond its stated justification and technical limitations are characterized by a strong need both by the parties and society for a high level of trust. They involve relationships in which one party must depend on the word of the other to engage in socially beneficial reliance. ${ }^{97}$ In the employee cases,

84 See Farber, supra note 10, at 310-22 (arguing that an economy without such institutional arrangements as insurance and credit would consist of a series of temporary equilibria that are not Pareto-optimal).

${ }^{\text {95 }}$ See id. at 325-29.

${ }^{86}$ The Tylenol incident was a dramatic example of the value of confidence. As long as people could be trusted not to tamper with medicines, medicines could be sold without elaborate safeguards. Once that trust was violated, it became necessary to spend millions of dollars for improved product security.

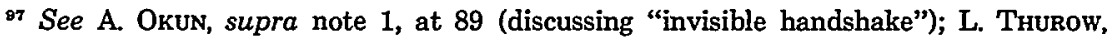


the socially beneficial reliance takes the form of higher job performance and lower turnover. In subcontracting cases, that reliance takes the form of a more efficient bidding process in which general contractors are able to give bids directly reflecting the information they receive from subcontractors. The point in these cases is not that reliance has taken place in a particular instance, but rather that reliance should be encouraged among participants in a class of activities. To restate our initial observation, the role of rehance in establishing liability and determining damages in individual cases is on the decline-but reliance, in the form of trust, is on the rise as the policy belnind legal rules of promissory obligation.

\section{B. The Proposed Rule}

A revised rule of proinissory obligation sliould accept the fundamental fact that commitments are often made to promote economic activity and obtain economic benefits without any specific bargained-for excliange. Promisors expect various benefits to flow from their promise-making. A rule that gives force to this expectation simply reinforces the traditional free-will basis of promissory liability, albeit in an expanded context of relational and institutional interdependence.

Our proposed rule is simply that commitments made in furtherance of economic activity should be enforced. Partial steps toward this rule can be found in section 90 of the Restatement (Second) of Contracts, as well as in various exceptions to the consideration doctrine intended to furtlier useful commercial arrangements. ${ }^{88}$ The proposed rule is a major departure from traditional contract law in that it requires neitlier satisfaction of traditional notions of consideration nor the specific sliowing of detriment associated witl promissory estoppel. But the rule sounds within contract law, and operates within its traditional area of concern: promissory economic excliange.

Just as the proposed rule emerges from recent judicial expansions of promissory estoppel, its boundaries are suggested by the limits of that expansion. Our survey demonstrated that courts liave

supra note 92 , at 195-215 (critiquing price-auction model as failing to take account of interdependency and cooperation in labor markets); see also Christensen v. Minneapolis Mun. Employees Retirement Bd., 331 N.W.2d 740, 747 (Minn. 1983) ("A conventional contract approach, with its strict rules of offer and acceptance, tends to deprive the analysis of the relationship between the state and its employees of a needed flexibility.").

9s U.C.C. \$ 2-205 (1978) (firm offers); Restatement (SEcond) \$ 87 (option contract); id. $\S 88$ (guaranty). 
been influenced to refrain from imposing liability by absence of a credible promise, absence of authority to make the promise, and absence of projected benefit to the promisor from economic activity. These factors also constitute the himits of promissory liability under the proposed rule.

$$
* * * *
$$

As included in the Restatement (Third) of Contracts, with accompanying comments and illustrations, our proposed rule would appear as follows:

\section{§ 71. Enforceability of Promises ${ }^{99}$}

\section{A promise is enforceable when made in further- ance of an economic activity.}

\section{Comment:}

a. Rationale and Relation to Other Rules. This section deals with what has traditionally been called consideration-namely, the legal conclusion that a promise is enforceable. Prior rules tested every promise or modification to determine whether the promise was conditioned on some tangible bargained-for exchange. The present section eliminates the need for finding a specific bargained-for promise or performance for each promise or modification. Rather, the key determination is whether the promise is designed to induce the creation of or to aid in the continuation of economic activity. The rule posits the social and economic utility of promises made in furtherance of economic activity.

The term "economic activity" includes sales of goods and services, leases, loans, insurance and employment arrangements, and similar transactions, whether involving businesses or individuals. The operations of organized charities are considered economic activities for purposes of this section. The requirement that the

99 Section 71 of the second Restatement, entitled "Requirement of Exchange; Types of Exchange," generally defines the requirement of consideration under traditional principles, namely, the presence of a bargained-for exchange. We have adopted that section number for our proposed rule of promissory enforcement, instead of the section number of promissory estoppel, to stress the close kinship between our proposed rule and traditional contract principles.

Our proposed rule covers the vast majority of situations previously handled by the doctrine of consideration. We do not, however, mean to foreclose the possibility that a few of the promises not enforceable under our provision might still be enforced on the basis of consideration. 
promise be "in furtherance" of the economic activity carries the implication that the promisor must expect a benefit to result from the promise. This expectation of benefit is to be demonstrated on the basis of an objective standard, and may often be presumed from the circumstances.

If the requirement of promise in furtherance of economic activity is met, there is no additional requirement of (1) a gain, advantage, or benefit to the promisor or a loss, disadvantage, reliance, or detriment to the promisee; (2) equivalence in the values exchanged; or (3) mutuality of obligation. Further, many of the promises denominated under the Restatement, Second, of Contracts as without consideration would be enforceable under this section if they occur in furtherance of economic activity. See, e.g., Restatement, Second, of Contracts $\S 87$ (options contracts), $\S 88$ (guarantees), $\S 89$ (modifications), $\S 90$ (promises enforced on the basis of reliance). Modern courts have made significant strides toward accomplishing the effect of this section by expanding the notion of the performance required for creation of a unilateral contract or by diluting the concept of reliance in promissory estoppel situations.

\section{Illustrations:}

1. A and B were employed as truck drivers for C. A and $B$ formulated a plan to become independent truck owners but still continue driving for $\mathrm{C}$. $\mathrm{C}$ gave $\mathrm{A}$ and $\mathrm{B}$ assurances of long-term employment and a sufficient amount of work to enable them to make payments on the trucks they purchased. After A and B purchased the trucks, $C$ refused to honor its commitment and terminated A and B. C's promise is binding and $A$ and $B$ are entitled to damages without regard to whether C's promises were "bargained for" or whether A and $B$ provided anything in exchange for C's promises. ${ }^{100}$

2. A, a long-time employee of $B$, accepts a promotion to a salaried position. At the time of promotion, B promised A that A would get pension credit for several of his previous years of service as an hourly employee not otherwise covered under the pension plan. When A retired, B refused to credit A's pension for the earlier period. B's promise is binding even though the express terms of the pension plan denied A credit

${ }^{100}$ See Glover v. Sager, 667 P.2d 1198 (Alaska 1983). 
for the earlier period, and without regard to whether A can show detriment or disadvantage. ${ }^{101}$

3. A and B are former husband and wife operating under a court-ordered dissolution decree and settlement agreement. After $\mathrm{A}$ is $\$ 7800$ in arrears on required payments, he and $B$ agree that $B$ will accept immediate $\$ 1000$ partial payment plus A's promissory note for $\$ 3500$ as full satisfaction of the outstanding obligation. Subsequently B brings suit for the full delinquent amount and $\mathrm{A}$ interposes the modified agreement as a defense. Because the promise was not made in furtherance of any economic activity, B's promise to accept less is not binding under this section. ${ }^{102}$ However, the promise may be enforceable under other principles of contract law. See, e.g., Restatement, Second, of Contracts $\S 73$ (performance of legal duty), $\S 74$ (settlement of claims), $\$ 89$ (modification of executory contract).

4. Corporation A prepared a bid for leasing a computer to Corporation B. A was running behind schedule and asked an agent of $B$ to pick up the bid at the airport. The agent, after agreeing to pick up the bid, declined to do so and the bid arrived too late for consideration. Assuming the agent acted within his actual or apparent authority, B is bound by the agent's representation. If A can show that it would have been awarded the lease, it can recover lost profits. ${ }^{103}$

b. Promises, Acts and Resulting Relations. ${ }^{104}$ This section requires that a promise have been made. A promise is a manifestation of intention to act or refrain from acting in a specified way, so made as to justify a promisee in understanding that a commitment has been made. A promise may be stated in words, either orally or in writing, or may be inferred wholly or partly from conduct. Compare Restatement, Second, of Contracts § 18-19 (manifestation of assent). Both language and conduct are to be understood in the light of the circumstances, including course of performance, course of dealing, or usage of trade.

${ }^{101}$ See Vastoler v. American Can Co., 700 F.2d 916 (3d Cir. 1983), discussed supra text accompanying notes 28-37.

${ }^{102}$ See Otten v. Otten, 632 S.W.2d 45 (Mo. Ct. App. 1982).

${ }^{103}$ See Universal Computer Sys., Inc. v. Medical Servs. Ass'n, 628 F.2d 820 (3d Cir. 1980).

104 The next two subsections draw heavily on the discussion of promises in RestateMENT (SECOND) \& 2. 


\section{Illustration:}

5. A leased property from B under a ten-year agreement, with an option for A to renew upon written notice for each of six additional five-year periods. During the second extension B died and C became trustee of B's estate. B had twice extended the lease on oral notice. $\mathrm{C}$ cannot enforce the contract provision requiring written notice if, under all the surrounding circumstances, a reasonable person in A's position would believe that B had committed himself to accepting oral notice. ${ }^{105}$

c. Opinions and Predictions. A promise must be distinguished from a statement of opinion or a mere prediction of future events. Whether manifestations rise to the level of a promise depends on various factors, including the clarity of the manifestations, the nature of the relationship between the parties, and the circumstances surrounding the manifestations.

\section{Illustrations:}

6. A, a long-term employee with B corporation, sues for severance pay after being separated from the company. The basis of A's claim is a portion of the employee handbook entitled "Separation Allowance." The Separation Allowance section states that " $[t]$ he inclusion of a schedule of separation allowances in the handbook, together with the conditions governing their payment, . . . is not intended nor is it to be interpreted to establish a contractual relationship with the employee." The last page of the handbook also contains an express, conspicuous disclaimer. Absent other circumstances indicating that B corporation had an express policy of not observing the stated limitations or that a reasonable employee would not have seen or understood the disclaimers, A's claim under this section fails. ${ }^{106}$

7. Physician B performed a tubal ligation on his patient, A. Several months after the operation B told A that A had nothing to worry about and that it was impossible for her to have any more children. Within a year A becomes pregnant. B's statement, in the context of the ordinary doctor/patient

${ }^{108}$ See Wachovia Bank \& Trust Co., N.A. v. Rubish, 306 N.C. 417, 293 S.E.2d 749 (1982), discussed supra text accompanying notes 56-57.

${ }^{106}$ See Kari v. General Motors Corp., 79 Mich. App. 93, 261 N.W.2d 222, rev'd, 402 Mich. 926, 282 N.W.2d 925 (1977). 
relationship, should have been seen as a mere therapeutic reassurance, not a promise. ${ }^{107}$

d. Agency limitations. Many promises that might otherwise be actionable under this section occur in a context where the party making the manifestations has neither actual nor apparent authority to bind the principal to the manifestations. See Restatement, Second, of Agency $\S \S 7,8$. Such lack of authority is particularly likely in large organizations where the manifestations are made by non-policymaking employees. The more substantial the hierarchical structure, the less likely that such manifestations represent authorized commitments. On the other hand, where such manifestations come to the attention of the principal and no effort is made to clarify or disavow them, the principal may be bound by the promises on the basis of affirmance or ratification. See Restatement, Second, of Agency $\S \S 82,83$.

\section{Illustration:}

8. A, a retail sales employee for a large department store chain, B, was told by her superior, $C$, that A would not be discharged except for just cause. Enforceability of this representation depends upon C's actual or apparent authority to bind B, or, absent such authority, upon conduct reflecting B's affirmance or ratification of such representations. ${ }^{108}$

$$
* * * *
$$

\section{Possible Objections to the Proposed Rule}

Several objections are likely to be made to a proposal that dispenses with reliance as a requirement for enforcing promises. ${ }^{109}$ First, it might be argued that reliance-based liability adequately

107 See Garcia v. Von Micsky, 602 F.2d 51 (2d Cir. 1979), discussed supra text accompanying notes 47-51.

${ }^{108}$ Compare the facts of Ryan v. J.C. Penney Co., 627 F.2d 836 (7th Cir. 1980), discussed supra text accompanying note 68, with those of MacEdward v. Northern Elec. Co., 595 F.2d 105 (2d Cir. 1979), discussed supra text accompanying notes 69-70.

${ }^{109}$ Although we have argued that proof of rehance should not be essential for the enforceability of a promise, this does not mean that reliance is a legal irrelevancy in all contexts. If a promise is otherwise enforceable but is subject to a procedural defense such as the statute of frauds, reliance may be a basis for overcoming the defense. See RESTATEMENT (SECOND) § 139. This article has been concerned with the core question of what kinds of promises are enforceable, and not with questions of form. We have also not addressed defenses such as lack of capacity, misrepresentation, and mistake. In these contexts, reliance may well be a crucial factor. 
protects the value of trust, which we have identified as the core concern of contract law. The main response to this objection is that reliance on promises in furtherance of economic activity often takes forms that are exceedingly difficult to prove. ${ }^{110}$ In the employment setting, for example, proving that an employee has worked harder or done a better job of training new workers may be close to impossible. The argument for enforcing such promises even in the absence of proof of reliance closely parallels the traditional argument for enforcing executory contracts without requiring proof of reliance:

Unless agreements can be relied upon, they are of little use. A rule of law that only protected a promisee who had actually relied upon a promise would, in practice, tend to discourage reliance. The difficulties in proving and valuing reliance are such that a person in business would hesitate to rely on a promise if the legal sanction were important to him. These difficulties are especially acute when a party has relied by forgoing other opportunities, as in the case of the buyer who contracts with a seller for the future delivery of apples and who would have made arrangements to get them from another source had the seller not promised to deliver them. "To encourage reliance we must . . . dispense with its proof."111

A second possible objection is that imposing liability on potential promisors will deter them from revealing information about their future intentions to those in the position to benefit from that information. ${ }^{112}$ The simple answer is that economic actors are free

110 Similarly, the difficulty of proving reliance damages answers the objection that a reliance measure of damages is adequate in promissory estoppel cases. In addition to raising problems of proof, limiting damages to recovery for reliance essentially amounts to qualifying the promise into a mere guarantee of compensation for reliance. But this lesser promise, if properly understood, will give rise to a lesser degree of reliance on the promise, and a lesser benefit to the promisor. While there is nothing wrong in principle with the making of a promise in the form, "I promise you either a pension or compensation for your reliance damages," there are dangers inherent in building such limits into the legal rule. See Farber, supra note 10, at 321 ("if damages are less than the full performance value of the contract, markets can collapse even if the vast majority of firms are trustworthy"). Such limits are also likely to allow promisors to take advantage of promisees' ignorance of legal remedies. Fortunately, modern promissory estoppel doctrine has not accepted the view that reliance is generally the appropriate measure of damages in promissory estoppel cases. See supra notes 22-26 and accompanying text.

${ }^{111}$ E. FARNSWORTH, supra note $3, \S 1.6$, at 18-19 (quoting Fuller \& Purdue, supra note 7, at 62) (citations and footnotes omitted). The traditional justifications for dispensing with consideration for options are similar. See Restatement (Second) $\$ 87$ comment a.

112 Concern about deterring promises is central to the Goetz and Scott approach. See Goetz \& Scott, supra note 4, at 1281-83 (attempting to set optimal damage rule at a level 
to make any statements they desire without fear of liability, so long as the other party understands that they are not committing themselves, are stating only their current intentions, and may change their mind at any time. In other words, where potential promisors are less than confident of their future conduct, the proposed rule fosters better information transmission by encouraging them to reveal their uncertainties. This information will help to insure that promisors will be trusted only insofar as they are worthy of trust.

A third objection is that legal liability will deprive economic actors of needed flexibility. But flexibility is not hampered by requiring accurate disclosure of uncertainty. If a promisee is not made aware that the promise made to him is meant to be flexible, the promisee's conduct will be premised on a false understanding of the seriousness of the promisor's commitment. Experience with misleading promises will lead to reduced reliance on future promises more deserving of trust-a result which in the end diminishes the flexibility of economic actors in general. Furthermore, the interest in flexibility is not well served by current doctrine. Under current law, a promisor's ability to retract a promise is severely limited by uncertainty as to whether promisees can prove detrimental reliance-a requirement that is rapidly becoming less demanding. In short, flexibility is best created by the combination of accurate disclosure and predictable enforcement.

Another objection is more general. Why should someone who has neither relied on a promise nor given anything in exchange for the promise be able to sue the promisor? Does a promisee who has neither incurred a detriment nor conferred a benefit receive a morally undeserved windfall from enforcement of a promise? Three moral arguments can be made in favor of plaintiffs suing under these "naked" promises. First, these plaintiffs are suing under a legal rule that itself has a moral claim to acceptance. If our underlying theory is correct, the rule benefits all economic actors in the long run. ${ }^{113}$ Thus, the rule would gain universal acceptance behind only the thinnest Rawlsian "veil of ignorance" and therefore creates not only legal but moral claims. ${ }^{114}$ Second, if these plaintiffs are not allowed recovery, the defendant may be said to enjoy a windfall. Having made a promise in order to capture a benefit for

\footnotetext{
that will not deter large numbers of beneficial transactions).

113 See supra text accompanying notes 89-97.

114 See generally JoHN RAwLS, A THEORY OF Justice 3-192 (1971) (discussing the principle of "justice as fairness").
} 
himself, the defendant cannot fairly be allowed to enrich himself by breaching the promise. In other words, a strong element of potential unjust enrichment is present. Third, promises may be thought to create moral obligations over and above the obligations enforced by the legal system on the basis of the technical requirements of considerations or reliance. ${ }^{115}$ Hence, any plaintiff suing on a promise has at least a prima facie moral claim to enforcement.

The most telling objection to our rule builds on this last argument and suggests that our rule does not go far enough. Why not provide for enforcement of all promises, rather than limit enforcement to those promises made in an economic setting? Although we have defined "economic activity" broadly, ${ }^{116}$ some promises clearly are not included, such as intrafamilial donative promises. Unlike promises made in an economic setting, these promises are not generally made to coordinate activities or generate reliance beneficial to the promisor. ${ }^{117}$ The presumption of utility that underlies our proposed enforcement of promises in furtherance of economic activity thus does not apply to such donative promises. This response, however, merely underscores the fact that our approach reinforces the moral value of trust only insofar as trust serves to support the functioning of the modern economic system.

We accept this characterization of our approach, but do not take it as a criticism. While the proposed rule addresses the often

11 For an elaborate discussion of promise as creating a moral obligation, see C. Fried, supra note 12, at 7-21 (1982). Our defense cannot, however, rest strongly upon Fried's stimulating discussion; we view Fried's position as too individualistic to form a sound basis for promissory obligation. See Kronman, supra note 12, at 406-07.

116 See proposed $\S 71$ comment (a), supra text following note 99. For an argument for even broader enforcement of promises, see Knapp, Book Review, 82 Mich. L. REv. 932, 93847 (1984) (reviewing E. Allen Farnsworth, Contracts (1982)).

11 See Goetz \& Scott, supra note 4, at 1265-66 (noting the argument that donative promises do not necessarily move resources to more valued uses, so that the rationale for enforcement is to minimize harm rather than to consolidate economic benefit). For a discussion of some of the issues presented by enforcement of promises to make gifts, see Eisenberg, Donative Promises, 47 U. CHr. L. Rev. 1 (1979).

A donative promise with respect to property is functionally insdistinguishable from a declaration of trust. The establishment of a trust is, of course, sufficient to support recovery regardless of the existence of an enforceable promise under contract law. See RESTATEMENT (SECOND) of TRUSTS $\S 17$ (1959). It is noteworthy tliat at least one famous consideration case was actually a trust case in disguise. Hamer v. Sidway, 124 N.Y. 538, 27 N.E. 256 (1891), involved an uncle's promise to pay his neplew $\$ 5000$ if the nephew refrained from drinking liquor, swearing, using tobacco, and gambling until the age of 21 . The court lield tbat the neplew's reformed conduct was sufficient consideration to uplold a contract. But in disposing of a statute of limitations defense, the court also held that a later letter from the uncle (saying that the uncle "had the money in the bank ... and [the nepbew] shall lave tbe money certain") established a trust. Id. at 540, 550-51, 27 N.E. at 256, 258-59. The existence of tbe trust, even if gratuitous, supported recovery. 
divergent concerns of the law and economics and critical legal studies approaches, it would be foolhardy to claim to synthesize them into a unified alternative perspective. We have aimed to broaden the scope of contract law to acknowledge and reinforce the value of trust for the broad range of economic relations that shape our daily lives-economic relations that have been hidden from the scrutiny of traditional contract law. There are certainly other kinds of relationships that help to constitute the life of the community. The areas of law that govern these relationships-family law is an example-may well need to be reformed in order to protect values similar to those that we have identified in the field of contract law. ${ }^{118}$ But we do not expect that a single legal rule can begin to capture the full spectrum of social relations.

\section{Application of the Proposed Rule}

The effect of the proposed section 71 can be explored by applying it to a controversial recent case, United Steel Workers, Local $1330 v$. United States Steel Corp. ${ }^{119}$ which involved the closing of two steel plants near Youngstown, Ohio. Plaintiffs alleged that defendants had promised to keep the plants open if the workers made them profitable. Plaintiffs acknowledged that "the minimum features of a formal legal contract," such as a fixed contract period and "specified mutual consideration," were missing. ${ }^{120}$

Plaintiffs' primary claim was based on promissory estoppel. The district court rejected the promissory estoppel claim on three grounds: (1) no definite promise was made; (2) the individuals making the statements were not defendant's officers, but employees and public relations agents; and (3) even if a promise had been made, the achievement of profitability was a condition precedent of defendant's obligations under that promise, and the Youngs-

118 For example, some commentators have suggested that the American testamentary system be reformed in order to provide more fully for the maintenance of family members who were dependent on the deceased. See, e.g., Laufer, Flexible Restraints on Testamentary Freedom-A Report on Decedent's Family Maintenance Legislation, 69 HaRv. L. REv. 277 (1955); Note, Family Maintenance: An Inheritance Scheme for the Living, 8 Rut.-CAM. L.J. 673 (1977) (comparing British and American systems); see also Naresh, Dependants' Applications Under the Inheritance (Provision for Family and Dependents) Act 1975, 96 L.Q. REv. 534, 550-54 (1980) (arguing against a strong burden of proving dependency on the decedent). For a general discussion of the relationship between family, work, and government as focal points of dependency and security in the modern economy, see generally Mary Ann Glendon, The New Family and the New Property (1981).

119492 F. Supp. 1 (N.D. Ohio), aff'd in part and vacated in part on other grounds, 631 F.2d 1264 (6th Cir. 1980).

120631 F.2d at 1269. 
town facilities did not become profitable. ${ }^{121}$ The Sixth Circuit affirmed.

According to the approach set forth by our proposed rule, Local 1330 was wrongly decided. The employees and the company had, over the years, developed the kind of interdependent relationship that promotes action on the basis of an "invisible handshake." U.S. Steel must be understood to have sought economic benefits by leading employees to increase their efforts. A traumatic time such as that surrounding a possible plant closing creates both a need to cooperate to salvage the operations and an atmosphere of distrust. In such a setting, the need to reinforce trust with legal sanctions is especially strong.

Seen in the context of surrounding circumstances, the promises made and the authority of those making the promises were sufficiently clear to support recovery under the proposed section 71 of the third Restatement. As the appellate court noted, "It is beyond argument that the local management of U.S. Steel's Youngstown plants engaged in a major campaign to enlist employee participation in an all-out effort to make these two plants profitable in order to prevent their being closed."122 But local management was not the only source of this effort. Many statements were made by agents of U.S. Steel at all levels, from the chairman of the board on down, to the effect that operations would be maintained if the plant became profitable. ${ }^{123}$

121 Id. at 1277 .

$122 I d$.

${ }^{123}$ See, e.g., id. at 1273 (item p: a televised statement by the chairman of the board). The statement also mentioned the possible relevance of costs of compliance with environmental regulations, but U.S. Steel did not allege such costs to have arisen.

The credibility of the promise in Local 1330 is demonstrated by comparing it with a similar case in which the representations were correctly held not to constitute a promise. In Abbington v. Dayton Malleable, Inc., 561 F. Supp. 1290 (S.D. Ohio 1983), aff'd mem., 738 F.2d 438 (6th Cir. 1984), the statements forming the basis of the plaintiff's claim were clearly hedged. The president made clear that the only hope of keeping the plant open was by way of an $\$ 8$ to $\$ 10$ million plant conversion: "Now, the Board of Directors of our company . . . would first have to give us permission to spend that kind of money. They will not be willing to approve that kind of expenditure unless we can show them this foundry can be competitive, and it's simple-nobody would bet on a loser." 561 F. Supp. at 1307. Based on this statement, the union agreed to four concessions in its collective bargaining agreement. After a partial infusion of funds for conversion and a continued dechine in the plant, the board of directors voted to close the plant.

Plaintiffs brought suit on a promissory estoppel theory and the court granted defendant's motion for summary judgment. The primary basis for this decision was "the inevitable conclusion that no statements by any officers of DMI . . . constituted a definite promise to continue the operation of or to modernize the Foundry." Id. at 1297. This conclusion was founded upon the court's view that the president made clear that the decision rested with 
The appellate court's discussion then focused on the question of whether the Youngstown plants did in fact become profitable-with profitability identified as a condition precedent of the obligation that U.S. Steel was alleged to have incurred. The parties presented conflicting accounting methods to measure profitability. The district court adopted the methods proposed by U.S. Steel, those of "normal corporate profit accounting"; the appellate court stated that it could not hold that "the District Judge erred legally or was 'clearly erroneous" " in so doing. ${ }^{124}$

The appellate court faulted the plaintiffs for defining profit as the difference between the direct costs of a plant's operations and the total selling price of its products. While stating that "any multiplant corporation could quickly go bankrupt if such a definition of profit was employed generally and over any period of time,"125 the court acknowledged that "this version of Youngstown profitability was employed by the Youngstown management in setting a goal for its employees and in statements that described achieving that goal."126 And, beginning in April, 1978, and continuing through November, 1979, the company commented to both employees and the public that the plant had become profitable according to those standards. ${ }^{127}$

The representations of profitability were unequivocal and were calculated to invoke the workers' trust. Nonetheless, both the district and appellate courts found that the employees should not have relied on these representations.

The standard of Restatement (Second) of Contracts $\S 90$, upon which plaintiff-appellants rely, however, is one of reasonable expectability of the "promise" detrimentally relied upon. The District Judge did not find, nor can we, that reliance upon a promise to keep these plants open on the basis of

the board of directors of the corporation, and that while the contract concessions were conditions to the board's consideration of the proposed plant conversion, they would not necessarily determine its decision.

The communications in Local 1330 were of a different character. The employees were told frequently that the decision of the board of directors would rest on profitability. Had U.S. Steel chosen to say, "The decision is entirely at our discretion, but we will look favorably on increased productivity as one factor influencing that decision," the company would have been free to do so. But U.S. Steel chose a different strategy.

${ }^{124}$ Local 1330, 631 F.2d at 1279.

${ }^{125}$ Id.

${ }^{128} I d$. (describing calculation according to which Youngstown was said to have made a profit in October, 1977).

${ }^{127}$ Id. at 1271-74. 
coverage of plant fixed costs was within reasonable expectability. ${ }^{128}$

In short, the employees relied on the promise as the employer intended, but their reliance was not "within reasonable expectability."

We find this result unconscionable. Whatever the prevailing definition of "profit" in corporate accounting, a continuous and consistent pattern of declaring the plants profitable, commending the employees for their achievements, and urging them forward should have tipped the scales against defendant U.S. Steel on this issue. There can be little doubt from the steady stream of communications about the achievement of profitability that employees did as they were expected to do when they relied on the representations of profitability.

The fact that the Local 1330 courts placed such emphasis on the meaning of one term, "profitability," may well underscore the need for a rule which, like the proposed section 71, examines the full context in which promises are made with a view to their social effects. The district court best described the nature of the relationship between U.S. Steel, its employees, and the surrounding community: "Everything that has happened in the Mahoning Valley has been happening for many years because of steel. . . . [T]o accommodate that industry, lives and destinies of the inhabitants of that community were based and planned on the basis of that institution: Steel."129 U.S. Steel had drawn "the lifeblood of the community" for its many years in the Youngstown area. ${ }^{130}$ The company had a strong community base and a stable work force that was willing to engage in the kind of long-term planning and commitment which is economically beneficial and perhaps even essential to a major industry. ${ }^{131}$

However U.S. Steel might have understood its long-term economic interests, there can be little doubt that it received economic benefits from the extraordinary efforts of its workers in the period between the initial rumors of shut-down and its final decision to close the Youngstown plants. As the Virginia Supreme Court observed in a similar case, a company needs "the continued services of loyal and efficient employees" to perform the task of winding

\footnotetext{
128 Id. at 1279.

120492 F. Supp. at 9.

$130 \mathrm{Id}$. at 10.

131 Id. at 9-10.
} 
down operations. ${ }^{132}$ Although that case involved the use of promises of severance pay to achieve orderly sale of the company as a going concern, the court's basic observation that major readjustments require industrial peace applies to plant closings as well. In either case, continued productivity and avoidance of damage to property enhance the value of the firm's resources.

In the long run, allowing breach of the employer's promise in this situation injures society as a whole. Employees will be less likely to put forth the extra effort to save a plant if employers can violate their promises by semantic quibbles. In breaching its understanding with its employees, U.S. Steel polluted the pool of trust from which it had drawn. The pool is large and individual breaches of trust may be small, but the effect of pollution is cumulative. Not only justice to the employees, but also society's interest in preserving the integrity of a vital social resource, require enforcement of the employer's promise in this situation. The proposed section 71 would do just that.

\section{E. Critical Legal Studies and the Proposed Rule}

Although we have focused on the economic rationale for our proposed rule of promissory obligation, the rule is also bolstered by moral considerations. Like the critical legal scholars, we view human social life as a positive good, and we believe that contract law implicates communitarian values. The value of trust, which forms the basis of the entitlement to rely, is the starting point of our theory of promissory obligation. Reliance is not protected in order to compensate individuals who liave suffered a wrong, as some writers have argued. ${ }^{133}$ Rather, promises are enforced in order to foster a society in which people can confidently rely on each other. Such a society is morally superior to the state of constrained avarice depicted by "bad man" theories of legal obligation. ${ }^{134}$

As the above discussion of Local 1330 demonstrates, however, our approach differs from what might be expected from the critical legal scholars. Duncan Kennedy, working from a critical legal studies perspective, agrees that the plaintiffs in Local 1330 should have prevailed, but for different reasons:

132 Dulany Foods, Inc. v. Ayers, 220 Va. 502, 508, 260 S.E.2d 196, 200 (1979).

133 See, e.g., Patrick Atiyah, Promises, Morals, and Law 40-42 (1981).

${ }^{134}$ See Oliver Wendell Holmes, Jr., The Path of the Law, in Collected Legal PaPERS 170 (1920). For the contemporary manifestation of "bad man" theories, see generally $R$. PosNer, supra note 11 , at 65-71, 88-94. 
The case was wrongly decided because the court should have implied into every contract of employment between the company and an individual worker the following term: As part payment for the worker's labor, the company promised that in the event it wished to terminate the manufacture of steel in the plant, it would convey the plant to the union in trust for the present workers (along with recently laid-off and retired workers). The company further impliedly promised to condition the conveyance so that if the union as trustee attempted to sell the plant or convert it to a use that would substantially reduce the economic benefit it generated for the town, the town would become the owner in fee simple. I would make this implied promise on the part of the company non-waivable .....135

Kennedy would imply such a term in order to achieve the three objectives that, according to his theory, form the basis for contract enforcement: paternalism, the redistribution of wealth, and efficiency.

To Kennedy, a properly paternalistic court would recognize that

[a] basic reason why workers have not in the past bargained for and won the kind of property interest in manufacturing enterprises that this term would represent seems to have been that they have miscalculated their true interests. They have underestimated the long-term value of worker control .... . They have overestimated the stability of basic arrangements between labor and management, and also overestimated the benefits of a relatively quiet life, with plenty of material goods and no responsibility. ${ }^{136}$

In short, "[p]eople are idiots,"137 and courts must engage in paternalistic intervention to save them from the effects of false consciousness.

Professor Kennedy is not explicit as to the redistributive ef-

${ }^{135}$ Kennedy, Distributive and Paternalistic Motives in Contract and Tort Law, with Special Reference to Compulsory Terms and Unequal Bargaining Power, 41 MD. L. REv. 563,630 (1982).

136 Id.

137 Id. at 633 . Real uncertainty, rather than false consciousness, may account for why even rational actors would be hesitant to bargain for such a contract term. Even Kennedy admits to some uncertainty about the effects of his proposed rule. Id. at 631 ("if I had been the district court judge in the case, I would have imposed it, with some trepidation and a great deal of curiosity about what would happen next"). 
fects of his proposed solution. Because of his focus on the company's relationship with its employees and the town, he is likely to lose track of the benefits that might result from relocation. If a new plant were opened in another town, the residents of that community would gain the kind of benefits the Local 1330 plaintiffs were about to lose. From the perspective of wealth redistribution, the gainers might well be people who are presently worse off than the union members who are suing-particularly if the plant relocates in the Third World. Stated more generally, communitarian values must operate within a community, and the solutions to social problems are deceptively simple if the affected community is defined too narrowly. ${ }^{138}$

As to efficiency, Professor Kennedy generally overlooks one of the basic lessons of economics: firms are not passive in the face of legal rules. Their future conduct will be affected as they take the rules into account. For instance, faced by Kennedy's rule of law, companies will be reluctant to open new plants or to expand existing plants because by doing so they will be freezing their capital. Instead, they will move to jurisdictions with more favorable legal rules, or work a plant until it becomes unproductive for lack of capital improvement, leaving a worthless legacy to the workers and the town. To the extent they cannot do so, the return on capital will diminish-a result with possible effects on savings and economic growth that may be damaging to the economy as a whole.

Our own approach fosters many of Kennedy's goals, but within the constraints of economic reality. We do not categorically reject the possibility that employers should have non-negotiable duties of fairness toward employees, but we do see serious difficulties in such proposals. We take the more modest step of holding

${ }^{138}$ Feinman, supra note 4, at 858-59, suggests an approach to Local 1330 similar to Kennedy's. According to Feinman, "the case has potential for creative revolutionary thinking in addition to legal advocacy or mass organizing." Id. at 859.

Reconstructing the contract case [Local 1330] can help us visualize what a more just system would look like and what is necessary to achieve it. "Freedom of contract" in the utopian vision requires a social order in which people possess the practical ahility to connect with each other to find meaning in their lives through common endeavor, a freedom that denies the life and death power of distant corporate managers over workers and their town.

Id. at 859-60. Again, however, while we find the goal laudable, a more realistic approach is necessary. Steel is not a local industry. A steel plant uses raw materials brought from distant markets, and sells products to firms that themselves have far-flung markets. Maintaining an inefficient plant in Ohio might require eliminating foreign imports, which would harm not only American consumers but also workers in Japan and Korea. It is not just "distant corporate managers" who exercise life and death power over steel towns; it is also the world economy. 
employers to their express representations. This approach does not protect against the distortions created by false consciousness. But it is likely to protect against the exploitation of employees by employers who falsely appeal to employee self-interest by making promises they do not keep. We believe this is an approach that courts are beginning to take, and one that is worth taking.

\section{CONCLUSION}

The traditional view of contract law divides promissory liability into two categories. By far the larger category involves tlie bargained-for exchange of promises for other consideration. These bargains are enforced, even in the absence of rehance, in order to protect the parties' expectation that future conduct will be governed by present commitments. The other, much smaller category, is that of promissory estoppel. Here, liability is imposed to remedy the injury to promisees who have relied on promises in vain.

Based on our survey of recent promissory estoppel cases, we believe that promissory estoppel is losing its link witli reliance. In key cases promises have been enforced with only the weakest slowing of any detriment to tlie promisee. Reliance-based damages are the exception, not the rule. With the dechne of reliance, promissory estoppel is moving away from tort law. It has become a means of enforcing promises differing in doctrinal detail from traditional contract law but sharing a common goal. That goal, we have argued, is to foster trust between economic actors. Trust is a moral good, but it is also an economic asset. It allows coordination and planning between economic actors and fosters the formation of valuable economic institutions.

Perhaps in an earlier age traditional contract law was adequate to foster the degree of trust society needed in economic activities. Today, an increasingly interdependent society needs to foster trust in a variety of relationships not readily organized through the device of the formal contract. Promissory estoppel is one of several mechanisms courts have used to try to close what we have called the "relational gap" in contract law.

In our view, recent cases expansively applying promissory estoppel are steps on the road to a broader rule of promissory obligation. We have proposed as a new standard for enforcement that all promises made in furtlierance of economic activities be enforced without regard to the presence of consideration or reliance. Altlougli we recoguize that courts liave not yet articulated this standard, we believe they are moving in this direction.

We do not wisl to overstate our claims for our approach. Like 
Corbin, we are skeptical of claims that the common law can be reduced to a simple set of rules, as well as claims that the proper resolution of contracts issues can be deduced from some set of abstract principles. ${ }^{139}$ And although we think our description of the cases we surveyed is a fair one, we certainly do not claim that every case can be neatly fit within our framework. ${ }^{140}$ Law is much too untidy for that. Perhaps most importantly, our rule does not pretend to be an eternal verity. It is tailored to provide for enforcement of promises in the kinds of relationships that are central to the contemporary economy.

On the other hand, we do believe that our approach is a distinct improvement over that of the current Restatement. As a description of the cases, the current section 90 offers very little guidance because it fails to identify the factors that are actually decisive in determining the outcomes of the cases. Our proposed section 71 admittedly does not account for every case, but it does provide much surer guidance in understanding the case law. As a normative statement, the promissory estoppel doctrine expressed in section 90 has raised more questions than it has answered. In every case, it has required that courts return to first principles to ask whether "injustice can be avoided only by enforcement of the

${ }^{138}$ As Professor Corbin put it:

So far as human history has gone, the fact is that we do not wish to enforce all promises and the courts have not enforced all promises. Therefore, we must continue to determine the factors that make promises enforceable; and our legal history will compel us to do this under some such title as "consideration." Doubtless, this would not be denied by those who have suggested the abandonment of the "doctrine." It may well be that they had in mind some specific form of doctrime that, like the present author, they knew did not explain all the cases. The American Law Institute has adopted a definition of "consideration" that limits it to something that is bargained for and given in exchange for a promise; but immediately it devotes ten sections to inform us what other factors will make a promise enforceable. The term "consideration" can be totally abandoned as well as limited; we should then instantly be obliged to consider, under other descriptions, the factors that will make a promise enforceable.

... However variable and widely or narrowly inclusive the usage of the term "consideration" may be, we shall have to struggle along with it in the process of differentiating between enforceable and non-enforceable promises.

1 A. Corbin, supra note $3, \S 111$ (footnote omitted).

${ }^{140}$ For example, our proposed rule does not attempt to address the issue of past consideration. See, e.g., Webb v. McGowin, 27 Ala. App. 82, 168 So. 196 (1935) (enforcing a promise to pay an annuity to a man who was severely injured while saving the promisor's life). The second Restatement's explanation of this result is keyed to the benefit received by the promisor. See Restatement (SECOND) $\$ 86$ comment d, illustration 7 . We suspect, however, that the harm suffered by the promisee is at least as important in understanding the result. In any event, although we do not question the result in $W e b b$, we have made no attempt to incorporate it within our proposed rule. 
promise."141 Busy judges, we think, deserve better guidance.

We do not claim to have finally resolved the problem of promissory obligation. We do contend, however, that our approach is both a distinct improvement over the current view and a modest step toward a fairer social order.

14 Restatement (Second) \$ 90. It may well be tbat all legal rules are ultimately based on the moral values of the judges, and that hard cases may require a judge to resort to consulting these values directly. As the quoted language shows, however, the current section 90 makes every case a hard case. Indeed, since the remedy "may be limited as justice requires," the remedy becomes a separate issue again requiriug a resort to ultimate moral values. If we are going to include rules this indeterminate in the Restatement, we might as well do a little editing of section 90 and reduce all of contract law to a single rule: "a promise is binding . . . if injustice can be avoided only by enforcement of the promise." 